\title{
Classificação de Cargos: Uma Perspectiva Histórica
}

\author{
Raymundo Xavier de Menezes
}

\begin{abstract}
$\mathrm{N}$
\ AO é propósito nosso fazer um relato completo do desenvolvimento global da classificação de cargos através de todo o Universo, mesmo porque para tanto não contariamos com dados suficientes nem margem adequada de tempo disponivel dentro de nossa programação. No momento, nosso objetivo restringe-se, apenas, a uma interpretativa explanação sintética, onde se refiram alguns marcos tidos como fundamentais para a compreensão cabal da problemática brasileira, concernente ao assunto.

Há fatos de ordem externa e de ordem interna que de certo modo condicionaram o processo evolutivo da classificação de cargos dentro de nossas fronteiras. Tais fatos podem situar-se em três planos, isto é, no plano supranacional, no plano internacional e no plano nacional. E' nessa ordem que vamos examiná-los e formular conclusões a respeito.
\end{abstract}

\section{PLANO SUPRANACIONAL}

Sob o prisma histórico nem sempre se pode desvincular, inteiramente, a classificação de cargos da administração de pessoal, do mesmo modo que esta não poderá dissociar se da administração em geral. Suas raizes muitas vêzes são comuns ou interdependentes durante prolongados periodos de mútua evolução. Nesse estágio é pràticamente impossivel delimitar ou distinguir o campo de progresso específico referente a cada uma delas ou focalizá-las em estudo, isoladamente, neste ou naquele país do Universo, de modo autônomo ou independentemente, para distinguir características ou traços individualizadores.

Não há dúvida de que foi o desenvolvimento das grandes burocracias a determinante do fenômeno classificação de cargos na sua feição atual, fenômeno êste, porém, cuja gênese ocorreu de há muito, antecedentemente, com a formação e padronização de cargos em geral. 
Com efeito, não é nova a idéia de estabelecer-se distinção entre as atribuições e responsabilidades dos membros de um mesmo grupo. A instituição da família constitui exemplo frisante, corroborador dessa assertiva, onde primitivamente na sociedade conjugal marido e mulher assumiram obrigações e responsabilidades próprias e definidas na manutenção dos lares.

Por outro lado, em qualquer grupo, desde as organizações tribais, a função do chefe sempre se destacou dentre tôdas e, segundo os progressos sociais, outros postos logo se afirmaram como unidades individualmente caracterizadas e conceitualmente padronizadas.

Manifestação tambẻm dessa tendência é o surgimento do proprietário ou gerente em contraposição aos empregados ou ajudantes no alvorecer da pequena emprêsa, nos primórdios da economia capitalista.

Essas separações preliminares deram-nos a idéia de cargo, ao passo que na fase da indústria artesanal, com o estabelecimento de diferenciações entre aprendizes, artifices e mestres, cada qual encarregado da manutenção de certa atividade e merecendo discriminação em matéria de tratamento social, surgiu-nos o exemplo da formação de profissões ou classes específicas.

No dominio público, desde a remota antiguidade, a organização social, nas suas origens, desenvolveu-se consoante com essa tendência. Primeiro o chefe ou rei e depois seus favoritos ou áulicos sobressairam no grupo como detentores das posições matis elevadas, após o que outros se foram sucessivamente destacando numa ordem distributiva de prestígio e autoridade, colocados em graus diferentes de hierarquização.

Também constituem antecedentes lógicos do moderno movimento de classificação de cargos a estruturação de castas, exércitos e instituições religiosas, pois nesses agrupamentos, de igual modo, a separação de atividades e a diferenciação de tratamento entre as várias categorias de associados eram erigidas em norma regular de procedimento.

No comêço essa separação operou-se empìricamente de cima para baixo, como conseqüência inevitável das condições sociais reinantes no momento. Tratando-se de proporções reduzidas, era então possivel que o homem se orientasse sem necessidade de vencer obstáculos de maior monta, isto é, a aplicação das regras elementares do bom senso bastava-lhe para assegurar o êxito, ao defrontar-se com qualquer situação concreta. 
Êsse estado de coisas prevaleceu até mais ou menos meados do Século XIX, sem discrepâncias fundamentais, em todos os países civilizados, cujas condiçôes sociais não favoreciam a ocorrência de desvios significativos no curso do processo histórico em desenvolvimento. Ao longo de sua duração, essa fase caracterizou-se sempre por tendência eminentemente empirica e completa ausência de propósito, ou seja, a evolução administrativa não era comandada por qualquer princípio cientítico ou objetivo consciente.

\section{PLANO INTERNACIONAL}

Com a maturidade da Revolução Industrial, então, é que, dada a complexidade crescente da estrutura interna das instituições, número de cargos e a variedade de atividades em certos setores ampliaram-se a tal ponto, que não era mais possivel dar crédito àquele processo primitivo. Já não se podia, com a mesma facilidade, estabelecer diferenciações entre cargos, nem indicar, com propriedade e justiça, o tratamento adequado a dispensar individualmente à multiplicidade de casos particulares apresentados.

A desordem interna dos serviços e as insistentes reclamações dos empregados alertaram os responsáveis, obrigando-os a mudanças de métodos e compelindo os a introduzir normas novas capazes de restabelecer o equilibrio perdido.

A necessidade de reformulação de procedimentos sentiu-se, então, de modo mais premente no âmbito do serviço público, não só em virtude do maior vulto e abrangência das respectivas organizações, ensejando o surgimento de problemas cada vez maiores e mais complexos e cruciantes, como, também, por fôrça da ma1or vulnerabilidade destas ao impacto de pressões populares. Realmente, enquanto no setor privado só se pensou em aperfeiçoamento sistemático de práticas administrativas, especialmente sôbre classificação de cargos, em função do movimento de racionalização do trabalho empreendido com o intuito de aumentar o rendimento dos serviços e pôr têrmo ao descontentamento reinante entre os empregados, no setor público de há muito era a idéia agitada para o fim de assegurar tratamento uniforme e imparcial à coletividade de candidatos ao ingresso ou de empregados admitidos no quadro de funcionários.

Em conclusão, pode-se afirmar que a revolta contra o protecionismo nas nomeações no âmbito da administração pública; reivindicações classistas, especialmente no que tange a salário, da parte dos empregados; e esfôrço de racionalização empreendido pelos empregadores particulares para obter maior eficiência dos 
serviços, tudo tendo como motivação o crescente vulto e complexidade das organizações, representam, assim, a mola mestra im. pulsionadora dessa mudança do comportamento social.

Esta fase assinalada como característica tipica da Revolução Industrial ao término de seu primeiro estágio e despontada pelos meados do Século XIX evoluiu normalmente, com reflexos uniformes nos principais paises industrializados, até às vésperas da I Grande Guerra, isto é, 1914. Sua feição própria, pode-se admitir, consistiu numa certa inquietação nos setores responsáveis pelo equacionamento e solução do problema, buscando, reiteradamente, na base de tentativas, reformulações da sistemática vigente, de molde a conseguir resultados novos e compensadores em face dos fins em vista, sem, contudo, obter, na prática, progressos significativos, em têrmos de aspirações globais.

Só em face das transformações motivadas pelas duas Grandes Guerras dêste século, oriundas e causadoras de cada vez maiores e mais complexas necessidades, teve inicio nôvo periodo no curso dessa evolução, cercado de melhores realizações práticas e promissor de novas conquistas em têrmos de progressos futuros.

Esta última fase, que se estende até nossos dias, influenciada pelas duas Grandes Guerras, bem como pelas contıngências pertinentes ao desenvolvimento das grandes emprêsas públicas e particulares que atingiram vulto imprevisto de complexidade, caracteriza-se pela formação e aprimoramento de uma ciência de administração, complementada por uma tecnologia administrativa, de que faz parte destacada a classificação de cargos pela fundamentalidade de sua missão.

Assim, de meras tentativas no sécuio passado, visando a encontrar solução para o problema do protecionismo gerador de iniqüidades de tratamento dentro do mesmo grupo social, a idéia da classificação de cargos generalizou-se a tal ponto, que figura hoje como instrumento indispensável à perfeita realização de tôdas as etapas constitutivas do processu e da técnica de administração de pessoal.

É que os postulados de racionalização do trabalho e justiça social, cada vez mais imperativos, obrigam o homem moderno, responsável pelo destino de uma instituição, a proceder com método e sistematização. Na verdade, foi-se o tempo em que o desperdício e baixo padrão de eficiência eram fatos normais admissiveis na vida das entidades sociais - mesmo purque näo se concebia a coisa de modo diferente - e a politica relativa ao trato com os empregados era ditada segundo a vontade patronal. Hoje, ao 
contrário, com os meios atuais de concorrência econômica e a participação cada vez maior e consciente do empregado no destino da Sociedade, proceder de tal forma será caminhar inevitàvelmente para o malôgro certo de qualquer empreendimento.

De fato, o administrador moderno vê-se a braços com problemas não sentidos em outras épocas, problemas êsses resultantes, por um lado, da complexidade crescente das emprêsas e, de outro, do conceito nôvo referente às relaçães dominantes entre empregadores e empregados. Por isto, de algum tempo para cá é ponto pacífico que as grandes organizações - e neste caso figura o Estado e seus desdobramentos como exemplo máximo - não podem prescindir de uma adequada classificação de seus cargos, racionalmente concebida e amoldada aos requisitos da técnica gerencial.

$E^{\prime}$ hoje, realmente, a classificação de cargos empregada em grande escala pelos governos, comércio e indústria dos paises mais desenvolvidos, onde a experiência resultante da prática continua e prolongada proporcionou a formação de uma técnica própria ainda sujeita a grandes aperfeiçoamentos, é verdade, mas já utilizada com proveitos bastante compensadores tanto para patrões, como para empregados e respectivas comunidades.

Entre os países berço dêsse movimento, os Estados Unidos da América, pelo espirito engenhoso e diligente de seu povo e o alto coeficiente de industrialização e desenvolvimento atingido, tomaram a vanguarda e têm, neste particular, desde muito, realizado progressos admiráveis. Com efeito, nâo é de agora que lá não se concebe boa administração em emprêsas que congreguem maior número de empregados, sem a existência de um plano de classificação de cargos em que possa apoiar-se continuadamente.

Sendo a classificação de cargos, tanto na estera estatal como nas emprêsas privadas, instrumento requerido pela industrialização para atender determinadas necessidades especificas surgidas a partir de certo estágio do desenvolvimento econômico e não se processando uniformemente, em todos os paises, a evolução dêsse fenômeno, constatam-se variações diversificadas no seu curso histórico de nação para nação, seja quanto à época do surgimento do fenômeno, seja quanto à forma, conteúdo e ritmo de intensidade de progresso conseguido.

Fatôres outros, entretanto, como intercâmbios de informações, conhecimentos e experiências entre paises culturalmente relacionados, tornando de interêsse comum os benefícios advindos de conquistas científicas e tecnológicas, tendem não só a minimizar tais disparidades inerentes a movimentos dessa natureza, como também ajudam a criar padrões regulares de procedimento, cuja validade 
imperando internamente em cada um, enseja a formação de modêlo definido, de uso generalizado e uniforme entre todos, fàcilmente identificável em vista das presentes correlações de semelhanças e afinidades constatadas.

A configuração dessa hipótese torna indispensável, muitas vêzes, que o estudo do assunto, para conhecimento completo da situação dominante em dado país, deve ser ampliado também àqueles onde procedentemente tenha a idéia e o progresso se originado e desenvolvido de forma modelar e condicionadora.

No caso especifico do Brasil, no que tange ao fenômeno classificação de cargos, vamos encontrar na Grã-Bretanha, no Canadá e nos Estados Unidos da América a base real e o lastro teórico que, em combinação com nossas tendências e condições sociais, determinaram, de modo marcante e significativo, o curso de nosso desenvolvimento. Dada tal circunstância, forçoso é que estendamos nosso estudo também àqueles países, para conhecer a fundamentação lógica de muitas das conclusões a que vamos chegar durante a análise do assunto no plano exclusivamente nacional. Para começar, façamos um resumo histórico do que aconteceu em cada um dêsses paises, èm relação à matéria.

Classificaçäo de Cargos na Grã-Bretanha - Como fàcilmente se depreende do exposto, na primeira fase, ainda embrionária, do movimento de classiticação de cargos, uma das feições predominantes consistiu na ausência de qualquer coloração nacional que imprimisse caracteristica de particularidade à evolução do processo neste ou naquele país. A regularidade das condições e dos tipos de comportamentos sociais, motıvada por idênticas espécies de necessidades emergentes, consentâneas com o adiantamento do progresso atingido ma1s ou menos em escala idêntica em tôdas as comunidades de significado expressivo, explica a afirmação dessa tendência durante tăo longo período da História Universal.

O caráter estratificado da Sociedade; a natureza rudimentar da tecnologia empregada; o comportamento rotineiro da massa trabalhadora; a padronização da formação profissional; a elementar complexidade, de modo geral, dos tipos de trabalho a executar; a morosidade caracteristica do processo de transformação no ambiente social; as proporções relativamente reduzidas dos vigentes tipos de organização; o conformismo com as práticas tradicionais; em uma palavra, a aceitação irrestrita dos usos herdados imposta pela desnecessidade de romper com o passado, para, descortinar novas perspectivas, acarretou, desde épocas imemoriais até os albores da Revolução Industrial, em todo o Universo, uma estagnação das práticas administrativas, consoante com o modêlo típico 
do comportamento da era medieval. Durante êste longo intervalo prevaleceu o primitivismo tradicionalista, com aprimoramentos quase imperceptiveis, pela minima gradação e máxima morosidade com que se concretizavam.

O ingresso na nova Era, determinado pelo desenvolvimento do processo industrial, não ocorreu, como é evidente, concomitantemente em todos os países civilizados e dai origina-se o descompasso de adiantamento històricamente constatado. Seja pela procedência ou pelo ritmo de ação, logo uns se distanciam dos outros, percorrendo trilhas distintas, para atender necessidades específicas.

Um complexo de circunstâncias de ordem variada fêz com que fôsse a Grã-Bretanha o campo propicio ao surgimento da primeira sociedade caracteristicamente industrial, assumindo posição modelar no concêrto das nações ocidentais, tidas como mais evoluídas nessa fase do progresso econômico.

Em conseqüência de incontido expansionismo, o primeiro setor a clamar por modificações e reformas toi a própria máquina estatal, assinalando o início, pròpriamente dito, das grandes burocracias, cujo crescimento e ampliação intervencionista para atender cada vez mais importantes necessidades coletivas, não parou até os dias presentes, dentro do panorama de nossa civilização.

O caráter de complexidade e a exigência de presteza inerentes às novas atribuições do Estado, aliados a um certo iluminamento da consciência coletiva em têrmos de reivindicações de tratamento igualitário dentro da comunidade ou de grupos dela integrantes, acarretaram, como primeira conseqüência, a desaprovação do conceito multissecular, segundo o qual os serviços administrativos a cargo do Estado eram de natureza tão simples, que qualquer cidadão estaria habilitado a executá-los. Foi indiscutivelmente a prevalência dêsse entendimento que dera lugar, com vigor crescente, naquele e, posteriormente, em outros países, à aceitação inquestionável, por longo tempo, do princípio e consequiente prática de que aos políticos cabia decidir discricionàriamente sôbre o provimento dos cargos públicos para premiar a fidelidade e o esfôrço proselitistas, assegurando, ao mesmo tempo, a base necessária à realização dos programas objetivados, depois de comprovada sua consonância com os anseios e aspirações coletivas, mediante referendo popular, demonstrado através dos resultados eleitorais.

Evidentemente, pela própria razão de ser dessa liberdade, os chefes politicos não estavam impedidos de incluir nas respectivas equipes seus intimos, amigos, parentes e aderentes, bem como os por êstes recomendados, prática essa, sã em suas origens, mas 
que, com o correr do tempo, foi deturpada e deu lugar ao mais desenfreado protecionismo na composição dos quadros funcionals, como regra geral em todos os países.

Se bem que aceito como soluçáo cabivel, ou mal necessario, êsse comportamento foi aos poucos provocando duplo desagrado, merecendo rejeição tanto por parte dos que não se beneficiavam na partilha, como dos que, anteriormente aquinhoados, se viam atingidos pelas vassouradas periódicas que as mudanças politicas impreterivelmente ocasionavam, para abrir claros e atender pressões incontornáveis, situação essa agravada pela crescente ineficiência observada em todos os setores do serviço público, decorrentemente do baixo nivel de preparo do funcionalismo e do clima desfavorável reinante nas repartições, merecendo a repulsa de tôda a comunidade. A revolta entre os britânicos contra êsse estado de coisas arrastou-se com crescente intensidade por século e meio, com protestos, críticas e sugestões de reformas, até 1855 , quando, por injunções devidas primordialmente à participação governamental na Guerra da Criméia, foi criada a Comissão do Serviçu Civil, com a atribuição definida de controlar a seleção de candidatos ao ingresso nos postos do serviço público e pôr fim às perniciosas influências politicas de caráter protecionista, para ensejar o surgimento do sistema do mérito como norma regular de administração.

Não obstante a evidência demonstrada em sucessivos relatórios como o célebre da comissão formada por Northcote e Trevelyan, e opiniões externadas por figuras de relêvo como John Stuart Mill, que certa vez afirmou: "A proposição de selecionar candidatos para o Serviço Civil do Govêrno mediante exames competitivos afigura-se-me um dêsses grandes melhoramentos públicos, cuja adoção será capaz de marcar uma era na história...", nem assim foi fácil a vitória da idéia.

Ao contrário, espiritos renovadores congregados em tôrnu da Comissão do Serviço Civil e mentalidades tradicionalistas implantadas em postos executivos e em consolidadas posições poli ticas colocaram-se em campos diferentes, travando prolongados debates e adiando as modificações requeridas.

Nesse choque de opiniões, a primeira vitória concreta do progresso surgiu por volta de 1860 , quando a maioria concordou $\mathrm{em}$ que protecionismo acompanhado da exigência de qualificações educacionais era bem melhor que protecionismo simplesmente, e que a seleção nessa base produziria reflexos benéficus no sistema educativo, tornando o mais atraente a nôvo contingente populacional. Nessa mesma época e em virtude dêsse entendimento, a 
Comissão do Serviço Civil advogou o agrupamento dos cargos para efeito de seleção, trazendo a dupla vantagem de simplificar o trabalho operacional e conseguir atrair maior massa de candidatos, entre os potenciais compreendidos no mercado de trabalho.

Embora tal idéia não tenha frutificado imediatamente, veio ela depois influenciar o desenvolvimento da classificação de cargos no govêrno inglês, até a época atual, tendo a favorecếla a pró!jria constituição e natureza de funcionamento da administração pública daquele pais.

Com efeito, como consigna Ismar Baruch no seu relatório "Position Classification in the Public Service", citando Morris 3. Lambie:

"Em contraste com a politica americana, o Govêrno inglês tem mantido os serviços amplos, definidos em têrmos mais ou menos gerais, de modo que permitisse maior liberdade na distribuição das tarefas. Além disso. atentando para os aspectos profissionais, tem pôsto em relêvo certa divisão de trabalho determinada, em parte, por uma definição ampla das tarefas de cada classe e também por um programa de seleção destinado a obter, para cada classe, certo tipo de servidor que, normalmente, estará satisfeito em permanecer e fazer carreira numa só classe. A classificação torna difícil, mas não impossivel, o acesso de uma para outra classe".

Essa generalização de atividades, caracterizada pela indefinição das tarefas correspondentes a cada cargo, decorrente, certamente em grande parte, de exigências de funcionamento do sistama de recrutamento da época em que imperava o protecionismo, reclamava, complementarmente, de cada empregado, após o ingresso, um aprendizado específico, para habilitá-lo a desempenhar o tipo de encargo conferido. Para tanto, porém, conforme o grau de dificuldade do trabalho, era necessária a posse de certo preparo intelectual.

Convém não esquecer que nesta altura dos acontecimentos o nascente Estado industrial tinha sua competência confinada, quase que exclusivamente, à ação controladora, executando predominantemente tarefas de natureza administrativa, principal e auxiliar, dando ensejo, de modo mais significativo, à ampliação numérica e qualitativa das funções de natureza burocrática.

Exigências de habilitação em têrmos de qualificações educacionais, caráter amplo das atribuições dos funcionários para ade- 
quar-se à indole do recrutamento e predominância de funções burocráticas nos quadros vigentes constituem, assim, fatôres condicionantes da origem e desenvolvimento da classificação de cargos naquele país.

Dentro dessas diretrizes, não obstante o processo do recrutamento continuar variando em cada Secretaria, o nôvo método de ação da Comissão do Serviço Civil produziu excelentes resultados, e com a elevação econômica e cultural da classe média, determinando alterações na dinâmica das fôrças sociais, por volta de 1870, como assinala G.A. Campbell em seu livro "The Civil Service in Britain", estava madura a idéia de eliminação do protecionismo e, portanto, favorecido o progresso da classificação te cargos.

Com efeito, foi, precisamente, em 1870 que surgiu o primeiro plano, compreendendo, apenas, os cargos burocráticos e estabelecendo os liames entre o recrutamento e o sistema de ensino. Foram, então, instituídas as classes simplesmente denominadas I e II, compondo-se aquela dos cargos correspondentes às atividades de natureza intelectual, e a última daqueles formados por tarefas de caráter rotineiro. Como salientou Ismar Baruch (obra citada). "Os da classe I seriam recrutados por meio de exames com base em curriculos universitários e responsáveis por tarefas de natureza administrativa e politica. Os da classe II seriam recrutados mediante exames menos rigorosos, de modo geral correspondentes aos currículos secundários. A maior parte dos trabalhos de escritório devia ser atribuída a êsse grupo".

Com essa conquista, novos estudos vieram a ser empreendidos para assegurar uniformidade de tratamento entre os vários órgãos do govêrno, principalmente no campo burocrático e, assim, o caos reinante em 1874, que justificou estudo sério e de profundidade, foi aos poucos declinando e já no fim do século era a idéia da livre competição de ingresso nos cargos públicos aceita, pacificamente, como regra geral.

Concebida originàriamente em função das exigências do recrutamento e complementada, para efeito de especialização profissional, pelo treinamento prático e objetivo, consolidou-se, de modo definitivo, a idéia da classificação de cargos no serviço civil inglês, sem grandes avanços, mas também sem qualquer retrocesso, até ocorrerem as transformações impostas pela I Grande Guerra, as quais se fizeram sentir não apenas neste, mas em todos os setores da Sociedade no plano internacional.

Se bem que exista classificação de cargos igualmente nos Ministérios e repartições autônomas, o plano oficialmente consi- 
derado limita-se ao quadro do tesouro, cujas atividades, pela sua natureza, importância e amplitude, sob o comando do PrimeiroMinistro, justificam essa peculiaridade. Em todo caso, cumpre lembrar que ao Tesouro competia exclusivamente decidir em matéria não apenas de contrôle numérico, condições e métodos de trabalho e estimativas orçamentárias, como também sôbre a classificação e salário do funcionalismo para todo o serviço público. Sua ação, assim, conjugada com a da Comissão do Sẹviço Civil, que, subordinada à Coroa, se encarregava do recrutamento, seleção e habilitação dos candidatos aos cargos públicos, era suficiente para assegurar o funcionamento do sistema em caráter geral, com uniformidade de tratamento em todos os setores, não obstante a aparente autonomia departamental.

Como anteriormente assinalado, as operações bélicas de 1914 a 1918 acarretaram transformações sociais marcantes de uma nova era na história administrativa de todos os países.

A Grã-Bretanha, fortemente atingida pela hecatombe, teve de tal modo conturbada sua administração, que de imediato reformas profundas foram reclamadas e, já em 1920, no que tange à classificação de cargos, o govêrno aceitava sugestões feitas por comissão reorganizadora de que participava o "National Whitley Council", no sentido de introduzir amplas alterações no sistema então vigente.

Em conseqüência foi aprovado um nôvo esquema, ampliando para quatro as classes existentes, cada uma subdividida em graus ou categorias intermediárias.

Ficou, assim, em posição mais elevada, a Classe Administrativa, compreendendo, em ordem ascensional, as categorias de principalassistente, principal, secretário-assistente, secretário-assistenteprincipal, secretário-delegado-permanente e secrétário-permanente.

Imediatamente abaixo ficou a Classe Executiva, com dois graus, conhecidos como de Treinamento e Superior.

Em terceiro lugar colocou-se a Classe Burocrática, também com dois graus, distinguidos com os títulos de Classe Burocrática e Classe Burocrática Superior.

Finalmente aparece na base do sistema a Classe de Assistente de Escrita, encarregada de operar as mais simples tarefas de escritório.

Fugindo ao padrão normal quanto à ausência de especialização das atribuições, passou também a existir um quinto grupo formado pelos Estenógrafos e Dactilógrafos, homogêneamente constituido e composto de quatro niveis hierárquicos. 
Evidentemente modificações similares, dessa e de outra natureza, ocorreram no âmbito departamental e com o passar to tempo, principalmente por fôrça das novas circunstâncias criadas pela II Grande Guerra, operaram-se fusões, desdobramentos e criação de categorias, tanto no plano geral como nos :ierviços especializados, consentâneamente cam a indole do sistema.

Assim é que um quadro mais recente apresentado por G.A. Campbell na obra já citada descreve:

a) a Classe Administrativa com seis categorias;

b) a Classe Executiva com seis categorias;

c) as Classes Burocrática e de Assistente de Escrita fundidas numa só e compostas por três categorias;

d) uma Classe de Serviço Exterior distribuída em nove graus;

e) uma Classe Científica com sete degraus;

f) uma Classe Médica com três niveis;

g) uma Classe de Psicologistas com quatro categorias;

h) uma Classe de Oficiais de Informação com seis categorias;

i) uma Classe composta de Arquitetos, Engenheiros, Agrimensores etc. integrada por quatro categorias.

Êstes são aspectos de um sistema protótipo adotado peì Govêrno, mas fora dêle ou the dando continuidade, também se pratica classificação de cargos em todos os setores da admunistração com respeito a qualquer tipo de emprêgo, pois de há muito há consenso geral de que tal procedimento constitui condição "sine qua non" para obtenção de eficiência no processo gerencial em qualquer esfera de atividade.

Classificação de Cargos no Canadá - Contrastando com o imobilismo característico da época anterior, a Revolução Industrial apresentou como feição marcante certo dinamismo expansionista em têrmos de idéias e técnicas valorizadas. O movimento originado na Grã-Bretanha tendeu logo a propagar-se em tôdas as direções, com tentativas por parte de outros paises, no sentido de absorver a experiência pioneira e conseguir iguais resultados quanto a desenvolvimento e progresso.

Dêste lado do Atlântico nenhum povo estava em melhores condições de receber essa influência do que o canadense, dada sua vinculação histórica e subordinação política e administrativa, integrando harmônicamente a mesma comunidade onde não podia deixar de prevalecer a identidade de interêsse e objetivos, não só no presente como em relação ao futuro. 
Dentro do mesmo programa de govêrno, idênticas diretrizes condicionaram a reforma do serviço civil britânico e do canadense para eliminar vícios, remediar males e sanear procedimentos aparentemente equivalentes e de natureza similar.

Com efeito, o desentendimento generalizado entre as Assembléias Coloniais e o Govêrno da Provincia em matéria de ação administrativa, pela indefinição de competências, gerou pernicioso protecionismo no provimento dos cargos públicos, criando situação a que não podia alhear-se o poder controlador central atuante na Metróple. Para corrigir êsse comportamento, avisos e recomendações, traçando convenientes diretrizes, foram expedidos pelo Ministério das Colônias e produziram conseqüências salutares até onde as condições reinantes o permitiram.

Maiores esforços no sentido de melhorar êsse estado de coisas conduziram à Lei de 1867, transformando a Província em Domínio, mediante a federação das várias colônias semi-independentes. Com essa medida, logo no ano seguinte foi aprovada a primeira lei de serviço civil canadense, tentando regular a organização e relações da vida funcional dos servidores públicos em geral.

Nos moldes da mãe pátria, foram criadas apenas duas categorias de funcionários, uma denominada interna ou departamental e outra conhecida como externa, cujo disciplinamento competiria futuramente ao Governador do Conselho. A primeira ficou dividida em quatro classes, sendo que a de Escrevente desdobrada em quatro niveis. Entre outros requisitos para nomeação constava a devida qualificação em exame. Segundo Charles H. Bland (Public Personnel Administration in Canada), em nenhuma época foi aquela lei considerada adequada, proporcionando, apenas, uma simples e frágil estrutura dos serviços.

A insatisfação em face dos resultados obtidos deu origem a quatro comissões reorganizadoras no periodo de 1868 a 1882 , cujos relatórios primavam por descrever situação verdadeiramente calamitosa. Disparidades salariais, favoritismo nas promoçōes, inflação de servidores temporários, excesso e escassez de lotação em umas e outras repartições, conduziram à conclusão de que se devia classifícar o funcionalismo de acôrdo com as atribuições, a antigüidade e o salário. Esta sugestão da primeira comissão, como as das duas que lhe seguiram, não se converteu, entretanto, em realidade.

A situação, ao contrário, continuou agravando-se. Os precários exames de qualificação foram pràticamente abolidos. $O$ Conselho de Serviço Civil chegou à beira da falência. O prestígio político substituia o mérito. Em síntese, reinava verdadeiro caos 
administrativo, cujo efeito salutar era provocar revoltas generalizadas "por não comportar o serviço público o ingresso de tôda a poptılação masculina do país" e despertar o sentimento quanto à necessidade de reformas.

Nessa conjuntura começou a trabalhar a quarta comissão designada em 1880. Constatando que as conseqüências desta situaf̧ão resumiam -se em ineficiência, ausência de incentivos, desperdício econômico, problemas para o Gabinete, pressões indevidas por partes dos caçadores de empregos e desprestígio na opinião pú blica, focalizou ela, tendo em vista as recentes reformas inglêsas para debelar o mal do protecionismo, duas importatnes recomendações: (a) criação de uma Comissão de Serviço Civil permanente e apolitica a quem o Gabinete confiaria a responsabilidade das nomeações; (b) nomeações mediante rigorosos exames competitivos.

O relatório com estas sugestões e outras não tão importantes conduziu às reformas das Leis do Serviço Civil Canadense de 1882 e 1886 que, em virtude dos compromissos assumidos com a situação dominante, não atingiram os resultados almejados.

Assim, com insignificantes alterações de comportamento em virtude dessas duas leis, continuou a administração inteiramente conturbada e cada vez mais se deteriorando até 1907, quando já havia consenso geral de que a influência da politica partidária e o vício do protecionismo estavam levando o serviço público a uma condição intolerável, precisamente quando a necessidade de maior progresso nacional e o aumento das responsabilidades do Govêrno reclamavam ação expedita da administração, cujo baixo salário oferecido e precaríssimas condições de trabalho já não atraíam quase ninguém fora do rebotalho.

Dedicando ênfase aos problemas aparentemente mais ligados ao sistenıa do mérito, o ato que reorganizou o Serviço Civil cánadense em 1908 adotou medidas bastante avançadas, mas no concernente à classificação de cargos limitou-se a separar o Serviço Interno em três divisões, de acôrdo com o salário percebido, e cada uma destas compostas de níveis A e B, preocupando-se geralmente mais com a forma de ingresso e permanência do servidor do que com as atribuições exercidas.

Apesar dos esforços, ainda desta vez os resultados atingidos não corresponderam aos propósitos motivadores. A Comissão de Serviço Civil não trabalhava com independência e ao lado da seleção corria o favoritismo, com desmedido aumento do pessoal temporário, além do que o serviço chamado externo, isto é, não departamental, continuava à mercê das injunções partidárias. 
De grande significado foi o relatório Murrey em 1912. Sir George Murrey, ex-Secretário Permanente do Tesouro Britânico, sensibilizou a classe politica com sua opinião abalizada. Depois de apontar uma série de incongruências, resumiu êle, segundo Ismar Baruch:

"Atribuo isto sobretudo a duas causas:

a) ao princípio estabelecido pela Lei de 1908, para classificar os funcionários então em exercício, o qual náo considerou devidamente a natureza das tarefas a desempenhar; $e$

b) a falta de uma autoridade coordenadora, corı podêres para tratar com todos os departamentos e regular-lhes a administração de pessoal de acôrdo com preceitos uniformes".

O advento da Guerra impediu, mais uma vez, que fôssem tomadas medidas legislativas acertadas, mas em compensação trouxe conturbações tão sérias, que reclamaram reformas inadiáveis em 1918. Foi então compreendido que era necessário como ins. trumentos básicos da reforma do serviço civil não apenas a ampliação do campo de autoridade da Comissão do Serviço Civil, como, também, o estabelecimento de um plano de classificação de cargos para o Serviço Público, obediente às seguintes diretrizes:

"1. As tarefas e responsabilidades inerentes a um cargo devem servir de critério para determinar-lhe a clas. sificação, visto que tais atributos constituem as caracteristicas fundamentais que diferenciam um cargo de outro e, ainda, todos os objetivos da classificação de cargos serão atendidos grupando-se substancialmente todos os cargos com tarefas e responsabilidades idênticas;

“2" Êsses cargos exigem pràticamente os mesmos requisitos de qualificações quanto ao currículo educacional, experiência, conhecimentos e habilidade de seus ocupantes e, por êste motivo, tais requisitos, dependentes como são do trabalho a executar, constituem base auxiliar para determinar a classificação própria de um dado cargo;

"3 Nem o grau de eficiência com que as tarefas de um cargo são executadas por quem o ocupa, nem a presença ou ausência de qualificações em seu titular, nem o pagamento que lhe é atribuido, nem qualquer outro 
fato dependente exclusivamente de sua individualidade, devem ser considerados como tendo influência na classificação do cargo; e

"4. Com os cargos deve adotar-se o grupamento prático mais simples, que sirva a todos os propósitos motivantes da classificação; de conformidade com êsse princípio, a unidade de classificação deve ser um grupo (chamado "classe") que, no serviço, abranja todos us cargos com tarefas e responsabilidades substancialmente idênticas, independentemente da lotação".

Foi, então, levado a efeito amplo levantamento para colhêr dados quanto ao número, categorias e atribuições de todos os cargos existentes e elaborado um plano de classificação de cargos lógico e sistemático, destinado a todos os fins da administração de pessoal, cuja aprovação pelo Parlamento se deu em 10 de novembro de 1919. Uma das linhas mestras dêsse trabalho consistia no reconhecimento da necessidade de sua atualização, com o correr do tempo, em caráter permanente.

De posse e se utilizando dêsse nôvo instrumento, conseguiu a administração pôr ordem em seus serviços e funcionar nos moldes de eticiência e imparcialidade há tanto tempo sonhados por verdadeira plêiade de idealistas reformadores.

A classificação de cargos concebida e efetivada no Dominio do Canadá difere profundamente daquela implantada no Serviço Civil inglês, traduzindo uma lição valiosissima para quantos se dediquem ao estudo dêsse assunto, em virtude de mostrar, através de longa e penosa experiência, o caráter de sua especificidade. Realmente, enquanto se procurava encontrar solução consentânea com o modêlo prevalecente na Metrópole, foram vãos todos os esforços despendidos.

Influência da política partidária na Administração Pública; protecionismo desregrado no ingresso e composição dos quadros do funcionalismo; ineficiência no rendimento dos serviços pela faltu de capacidade e pelo desestimulo reinante entre os servidores; iniqüidades gritantes de modo geral e dentro de cada repartição, em têrmos de tratamento dispensado aos funcionários; desprestigio do conceito de serviço público junto à opinião popular, tudo isto ocorria lá e cá e reclamava correção urgente e de modo cabal.

$\mathrm{Na}$ velha e tradicional Grã-Bretanha com uma organização estatal estratificada no que tange à contextura profissional; com uma opinião pública, de formaçăo multissecular, capaz de exercer 
pressões de natureza a condicionar os comportamentos éticos individuais em tôdas as camadas da sociedade; com um modelar e consolidado sistema curricular de ensino criador de um verdadeiro escalão de "status" na classe educada; nessa conjuntura circunstancial a implantação de um sistema do mérito ensejador da criação de uma elite instruida nos principais postos do serviço público bastaria para, com o tempo, debelar êsse séquito de vícios e males deturpantes. Nesse ambiente o importante era o homem em relação ao cargo e não o cargo em relação ao homem. Senso de responsabilidade substituía a minúcia regulamentar, como condicionalmente do comportamento funcional em nivel de padrões éticos exemplares. Em tal conjuntura. o indivíduo podia movimentar-se livremente dentro de sua profissão, consuetudinàriamente escalonada, galgando degrau após degrau, satisfazendo exigências de formação, nos moldes da carreira militar.

Assim ocorrendo, era irrelevante na estruturação do sistema a definição de tarefas e delimitação dos cargos, pois o homem e o pôsto eram uma e a mesma coisa.

Daí constatarmos na classificação de cargos inglêsa ausência de unidade, despreocupação de contrôle atualizado, falta de registros e prescrições, agrupamentos primários amplos e indefinidos, pairando sempre num plano de generalidades.

Êsse modêlo que em repetidas tentativas se procurou transplantar para o Canadá, ou assimilá-lo sem profundas modificações, não correspondeu à expectativa configurada em face do êxito obtido e conduziu ao malôgro de todos os empreendimentos levados a efeito nesse sentido.

Por quê?

Porque era outro o ambiente.

Em se tratando de uma comunidade em fase inicial de formação, faltava-lhe, em têrmos de sentimento coletivo, capacidade de compreensão e discernimento dos direitos e deveres coordenadores do equilibrio da vida do homem em sociedade. Tal ocorria em virtude de não contar ainda aquêle povo com um patrimônio de tradição e educação necessários à criação de um senso de responsabilidade gerador de elevado padrão de compor tamento social. Não havendo, ainda, consenso geral sôbre uma escala típica de valôres éticos nem, conseqüentemente, existindo uma opinião pública organizada, era, como a prática se encarregou de demonstrar, exagerado otimismo esperar espontânea e absoluta correspondência entre a ação individual e a expectativa de comportamento idealizada pelos mentores das reformas.

Nessas circunstâncias, ficou evidente não ser possivel atingirem-se resultados positivos, a menos que se instituisse e enfa- 
tizasse um autoritário sistema rígido de contrôle, capaz de pôr fim aos desmandos e abusos geralmente praticados, não só pelos empregados, como também por tôda a classe dirigente, para o que era necessário instituir-se o padrão com o qual devia conformar-se a conduta de ambas as partes.

Para conseguir se êsse objetivo, era imperioso efetivar-se uma inversão de principios, tendo em vista o que até então tinha sido praticado. Assim, a ausência de unidade, a despreocupação de contrôle atualizado, a falta de registros e prescrições, os agrupamentos primários amplos e indefinidos, pairando sempre num plano de generalidades, tido como principios característicos da classificação de cargos inglêsa, tiveram que ser virados pelo avêsso para apresentarem resultados compensadores. Similarmente, na estruturação de um sistema adaptado a essas circuns. tâncias era altamente relevante a definição de tarefas e delimitação dos cargos, pois agora necessário se tornaria considerar importante o cargo em relação ao homem, em vez de o homem em relaçăo ao cargo, para assim atingir resultados práticos correspondentes ao anseio alimentado.

E dêsse modo surgiu a nova filosofia de classificação de cargos com base nas atribuições e responsabilidades inerentes aos mesmos, colimando tratamento coletivamente uniforme e justo, para todos os efeitos, em têrmos de administração de pessoal. Registros minuciosos, contrôle central e atualização permanente para ensejar tratament em função de comportamento completam a feição dominante da nova sistemática concebida.

A experiência canadense nos proporcionou fecundo ensinamento, não apenas ao demonstrar que os insucessos não devem motivar desânimo ou tergiversação, como também ao evidenciar não ser imutável a forma de operar-se a classificação, mas, ao contrário, adaptar-se ela sempre, tanto quanto possível, às condições ambientes prevalecentes.

Classificação de Cargos nos Estados Unidos da América Só por questões de ordem didática justifica-se considerar separadamente a evolução da classificação de cargos no Canadá e nos Estados Unidos da América. Na realidade a aproximação física e as afinidades de interêsses e intercâmbios culturais fizeram com que ambos conjugassem esforços para obter êxitos comuns. Para corroborar essa assertiva, basta lembrar que ao escritório especializado de uma firma americana - Arthur Young and Company - coube o estudo final para elaboração e aprovação do plano de classificação de cargos canadense de 1919, sem esque cer que a antiga "Civil Service Assembly of the United States and Canada", cuja contribuição para o progresso do movimento de classificação de cargos se afigura inestimável, exercia sua ação de modo idêntico em ambos os países. 
Do ponto-de-vista cronológico, apenas em relação ao poder central, o Canadá levou vantagem sôbre os Estados Unidos, a quem, assim mesmo, coube a glória da iniciativa, além da liderança indiscutivel com respeito às demais áreas de govêrno, ao comércio e à indústria.

No que concerne ao assunto, em principio era idêntica a problemática inglêsa, canadense e norte-americana: protecionismo decorrente de influência político-partidária na administração e baixo rendimento, com desprestígio do serviço público. Dentro dessa conjuntura, procurou-se encaminhar a primeira solução no âmbito federal, mesmo antes de haver o inglês obtido qualquer êxito capaz de servir de modêlo válido.

Circunstâncias particulares imprimiram características próprias ao fenômeno "protecionismo" no solo americano. Com efeito, enquanto na Grã-Bretanha, e conseqüentemente no Canadá, êsse vício administrativo apresentava se com resquício do regime feudalista, onde o príncipe ou o rei exercia o múnus público arbitràriamente, premiando ou punindo a seu bel-prazer, nos Estados Unidos essa herança foi violentamente sobrecarregada pelas distorções concernentes ao funcionamento da vida partidária na nascente democracia.

O exercício do bom-senso havia estabelecido a praxe prevalecente nos outros dois países, segundo a qual os afastamentos de funcionários em decorrência de mudanças políticas limitavamse, estritamente, aos casos destinados a evitar a ocorrência de infidelidades partidárias. Também assim procedia em seus primórdios a nação americana, tendo mesmo, conforme ensina Leonard D. White em seu livro "Introduction to the Study of Public Administration", antes de organizados os partidos em escala nacional, prevalecido certo sistema do mérito, com bases lançadas, ainda, por George Washington.

Cedo, porém, essa isenção foi desrespeitada por John Adams ao dar preferência nas nomeações aos Federalistas, criando uma situação desfavorável aos republicanos jeffersonianos que em 1801 assumiram o poder. Thomaz Jefferson, com seu senso de equilibrio, concebeu a doutrina da "participação proporcional", permitindo que cada partido dispusesse, em partes iguais, de lugares na administração para empregar seus adeptos.

Mesmo assim, dado o referido comportamento federalista, a aplicação dessa doutrina determinou na época inúmeros afastatamentos para abrir vagas e assegurar o defendido tratamento político igualitário. Por outro lado, com o declinio dos Federalistas, a idéia evoluiu para "participação proporcional aos resultados eleitorais", certamente devido a influências de ambiente poli- 
tico estadual, onde as facções se batiam encarniçadamente pelo contrôle das nomeações aos cargos públicos. Foram êsses políticos, discordantes da tolerância Jeffersoniana, que engendraram a doutrina do monopólio partidário, aceita integralmente por Jackson em 1829 , restabelecendo o famigerado "spoils system", dominante no periodo da administração colonial.

As conseqüências desastrosas dessa orientação política não se fizeram esperar. Descontentamento generalizado, ineficiência administrativa, desprestígio da função pública, prevalecimento de interêsses particulares conturbaram, em alta escala, o funcionamento da máquina estatal. Em compensação, porém, as reações foram imediatas, e séria luta se travou com o fito de debelar êsses males tão perniciosos à vida nacional.

Protecionismo político na administração, indevidas discriminações de tratamento entre os empregados, baixo rendimento e desprestigio das repartições públicas eram causas e efeitos, cujos meios de eliminações se procurava descobrir na Grã-Bretanha, no Canadá e nos Estados Unidos. Afinidades históricas e intercâmbios culturais uniu-os na busca de uma solução comum e recíproco aproveitamento de experiências, cujos resultados não eram, entretanto, compensadores, dadas as condições ambientais diversas existentes em cada um dêles.

Já vimos como se passaram as coisas na Grã-Bretanha e no Canadá. Vejamos, agora, o que ocorreu nos Estados Unidos.

Preliminarmente, para facilitar a compreensão dos acontecimentos tal como se desenvolveram, convém lembrar alguns traços da indole do povo estadunidense.

Assim é que seu espirito de independência sempre o animou a exercer contrôle sôbre o poder constituido e ver nas organizações sociais os instrumentos destinados a servir aos individuos, para o que devem ser pressionados, convenientemente, da base para o tope.

Isto faz com que na vida prática, em têrmos de iniciativa e progresso, o setor privado se sobreponha ao setor público e neste as unidades menores caminhem na vanguarda e contingenciem o desenvolvimento das de nivel mais elevado, resultantes de sua união.

Por outro lado, sua pragmática filosofia de vida torna-o contìnuamente alerta às vantagens da eficiência e lhe induz o espirito de engenho e organização, sempre que se proponha atingir qualquer objetivo.

Foram essas qualidades que condicionaram a evolução da idéia de classificação de cargos nos Estados Unidos, de cuja 
experiência muito se beneficiou o Dominio do Canadá, como é fácil de se depreender.

Feitos êsses esclarecimentos, passemos ao relato, análise e interpretação dos fatos.

Como vimos, a adoção do "spoils system" na esfera federal decorreu de prática idêntica prevalecente nas inferiores esferas de govêrno, além da experiência colonial, e fêz sua "rentrée" gloriosa em 1829.

Evidentemente, o número de beneficiados por tal sistema não era elevado, cumprindo considerar que, do ponto-de-vista da prestação de serviços públicos, era tal prática prejudicial a tôda a comunidade. Além disso, mesmo os felizardos, depois de con seguirem uma situação, não se deleitavam com a ameaça de virem a ser substituídos. Dêsse modo, a despeito do fundamento lógico com que desejou o Presidente Jackson justificá-lo, alegando ver mais vantagem administrativa no rotativismo do que na permanência dos funcionários, repousava tal sistema, primordialmente, numa expectativa de vantagem, a qual, entretanto, como no caso das loterias, representava, inquestionàvelmente, forte motivação.

Configurado o quadro de ineficiência do serviço e parcialidade de tratamento e desprestígio do servidor, duas correntes poderosas se formaram contra a continuidade de tal estado de coisas, ou seja, os contribuintes e os próprios empregados federais.

Em virtude dessa dupla pressão, duas espécies de medidas eram requeridas dos legisladores: moralização e sistematização da vida funcional du servidor público, dizendo respeito a primeira à instituição de um sistema de mérito e a segunda ao estabelecimento de uma classificação ordenada dos empregos existentes.

A influência inglêsa é patente no equacionamento inicial de ambos os problemas, não obstante, como no caso do Canadá, a dessemelhança das condições existentes. Com efeito, as primeiras tentativas repousaram na premissa de que o ingresso de pessoal qualificado e a criação de algumas classes amplas, de linhas profissionais, constituiria solução bastante adequada, tal como ocorrera na mãe-pátria.

Assim é que, encarada a realidade sob êsse prisma, no tocante ao sistema do mérito, já na década de 1850 começaram a ser colhidos os primeiros frutos da campanha. Segundo William G. Torpey (Public Personnel Management), a partir de 1851 algumas repartições federais começaram a aplicar exames como método de seleção para ingresso de funcionários e em 1865 o Presidente Lincoln, no seu segundo periodo de govêrno, recusouse a efetivar os afastamentos e substituições requeridas segundo 
a praxe do tal "sistema de espólios". De igual modo, em 1872, - Presidente Grant tentou restringir o número de cargos usados como instrumento político.

$\mathrm{Na}$ década de 1870 , nos relata o mesmo autor, a repulsa contra o "spoils system" tornou-se cada vez mais intensa, atingindo o ápice em 1880 com a eleição de James A. Garfield, integrado no espírito da reforma, como Presidente dos Estados Unidos. O assassínio dêste homem público por um desvairado caçador de emprêgo mobilizou a opinião pública num sentido unânime a favor da reforma imediata que se cristalizou com o "Pendleton Acta", de 16 de janeiro de 1883, tido como verdadeiramente a primeira lei do serviço civil norte-americano. Com a criação de um órgão central controlador das atividades de pessoal em tôda a administração, segurança de estabilidade para o funcionalismo e instituição de exames competitivos na seleção de candidatos ao ingresso no serviço público, pensava-se haver com essa lei controlado a situação e resolvido o problema de modo cabal e definitivo. A realidade, todavia, veio indicar que alguma coisa ainda estava faltando.

Nesta época, algo também já havia sido conseguido, em têrmos de classificação de cargos, para impedir as flagrantes discriminações de tratamento de que eram vitimas servidores muitas vêzes integrantes de uma mesma categoria.

Evidentemente, numa democracia vigorosa, quase exuberante, - Congresso não podia deixar de tornar-se a caixa de ressonância das aspirações e preocupações das várias camadas populares. Uma destas, os servidores públicos federais, encontrava-se em situação privilegiada, dada sua origem política, significado de sua atuação em têrmos de vida partidária, proximidade e acesso fácil aos representantes do povo, podendo nạ̃o só apresentar nos momentos oportunos suas reivindicações, como acompanhar-lhes com zêlo a tramitação para evitar eventuais encalhamentos. Dêsse modo, não é de estranhar encontrassem os funcionários, dentro do Congresso, patrocinadores interessados na defesa de suas causas, as quais, por motivos óbvios, giravam, quase sempre, em tôrno de problemas salariais. Por outro lado, o corpo legisla tivo, como um todo, interessava-se pelo eficiente funcionamento da máquina administrativa, que só poderia ser obtido através do oferecimento de condições favoráveis a uma boa contraprestação de serviços da parte do funcionalismo.

A conjugação de fôrças dessas duas correntes durante longo periodo de verificações, estudos e tentativas de solução do problema contribuiu para fixar a noção de que devia haver salário igual para trabalho igual e isso só seria conseguido após "a descoberta de algum meio de classificar ou hierarquizar os cargos, 
uniforme e imparcialmente, na base de suas respectivas tarefas", segundo esclarece Ismar Baruch no trabalho anteriormente citado.

É ali igualmente consignado que desde 1789 , seja em projetos especiais ou em propostas orçamentárias, debatia-se o assunto em comissões executivas e legislativas, mas só em 1838, por insistência dos funcionários, apoiados pelos respectivos chefes, em vários ministérios e após reiteradas petições, resolveu o Senado aprovar resolução, exigindo dos ministérios relatórios que esclarecessem:

"a classificação dos escreventes... no que tange ao caráter do trabalho a executar, responsabilidades impostas, tensão e capacidade exigidas e valor relativo, para o público, dos serviços de cada classe, em cotejo com as demais..."

Foram, assim, assentadas as bases para uma boa classificação, muito antes que estivesse amadurecida a idéia e houvesse condições favoráveis a uma transplantação para a realidade. Anote-se, também, que a preocupação apenas com a classe dos escreventes indicava uma noção falha das condições ambientais existentes, pois numa nação nova, em via de formação, carente de uma estruturação profissional definida e de um consolidado sistema educacional adaptado às suas necessidades, o problema assumia proporções bem mais amplas do que as medidas recomendadas faziam presumir.

Ao correr dos anos, vários outros projetos de igual natureza tramitaram pelo Congresso, mas as primeiras providências através de diplomas legais só começaram a ser tomadas a partir de 1853 . Nesse ano e no seguinte foram sancionadas as primeiras leis destinadas a ajustar e uniformizar os salários dos escreventes, os quais foram grupados em quatro classes, cada uma com certa retribuição fixa estabelecida. Posterior e gradualmente essa tabela estendeu-se aos demais cargos burocráticos.

Não obstante a consciência do problema e as boas intenções e esforços no sentido de solucioná-lo por parte dos intéressados e responsáveis, nenhum progresso, além disso, foi conseguido até a aprovação da Lei do Serviço Civil de 1883, ou, para melhor dizer, até a Lei de Classificação de Cargos de 1923, no âmbito do Govêrno Federal.

A esta altura dos acontecimentos, todavia, já outras áreas, direta ou indiretamente, interessavam-se também pelo assunto, em face das dificuldades criadas pela crescente onda de industrialização no país, em ambos os setores público e privado de administração. Com efeito, a variedade em natureza e o aumen- 
to em amplitude e complexidade dos empreendimentos reclamavam mudanças de normas, métodos, processos e atitudes em gradação cada vez maior para atender, de modo expedito e adequado, às necessidades emergentes a cada momento.

A busca de maior eficiência para elevar a produção em grau correspondente às exigências de demanda do mercado de consumo despertou, em muitas emprêsas, o interêsse pela racionalização e melhoria dos processos e condições de trabalho, a fim de conseguir aumentar a eficiência dos empregados, oferecendo-lhes, em contrapartida, tratamento mais compensador, em têrmos de vantagens e retribuição salarial.

A experiência vivida já criara no ambiente a noção de cargo como elemento independente e condicionante da conduta do empregado, único meio de vencer os obstáculos criados pelas deficiências de formação ético-educacional e pela instabilidade do conteúdo inerente às profissões, tanto antigas como modernas, decorrentemente das transformações operadas no seio da sociedade. Novos inventos, novos hábitos e novas necessidades impediam ou anulavam qualquer padronização de comportamento tendente a regular as relações homem-trabalho ou patrão-empregado dentro das organizações.

Consoante êsse entendimento e tendo em vista a crescente complexidade do problema, a indústria privada, à medida que se expandia, começou a interessar $-s e$, de modo especial, pelas providências relacionadas com a análise de funções e medidas dos tempos e movimentos, a que se liga de forma imorredoura o nome do engenheiro Frederick W. Taylor, cognominado pai da administração científica.

Paralelamente, com a criação dos órgãos centrais de pessoal, em virtude da metamorfose das oficinas em grandes fábricas e a ampliação e revigoramento dos sindicatos incumbidos da defesa dos interêsses de classes, surgiu de forma premente e continua a necessidade de contar-se, à distância, com dados e informações concernentes ao comportamento dos empregados em atividade e relacionados com os encargos conferidos a cada um e com as exigências de qualificações para efeito de desempenho eficiente. Tanto para fins de administração como de contratos e negociações era de suma importância que o ordenamento de tais dados se conformasse com os propósitos de tratamento uniforme e generalizado a grupos de individuos, segundo a identidade ou semelhança das respectivas situações.

Tal conjuntura contribuiu não apenas para valorizar o "status" da administração do pessoal no conjunto das atividades intermediárias, como também para definir-lhe o campo específico, abrangido pelas suas múltiplas fases componentes, entre as quais se 
alinhou a classificação de cargos como instrumento básico a ser utilizado por tôdas as demais na efetivação de seus objetivos.

Ao atingir êsse ponto de desenvolvimento e comprovada sua utilidade prática nas mãos de empregadores e empregados, teve a classificação de cargos rápido progresso em extensão e qualidade no setor privado de administração, com a aplicação de novas técnicas e obtenção de resultados cada vez mais precisos e eficazes.

1 Bem de acôrdo com a indole nacional daquele país, conforme anteriormente referido, comprovada a eficácia dos novos métodos e processos administrativos no âmbito da indústria privada, começaram as pressões no sentido de estender tais práticas ao terreno da administração pública para melhorar o funcionamento das repartições em tôdas as áreas de govêrno.

Também de acôrdo com essa tendência, os progressos alcançados estavam na razão direta da proximidade com os contribuintes, isto é, o nivel de administração local antecipou-se ao estadual e êste igualmente ao federal.

Assim, enquanto provavam-se infrutiferos os esforços consolidados nos projetos do Congresso discutidos em 1886, 1905 e 1907 e tendentes à instituição de um plano avançado de classificação dos cargos ocupados pelos servidores da União, coroava-se de êxito em 1912 a tentativa da cidade de Chicago, iniciada em 1905, no sentido de aparelhar-se com uma moderna classificação de cargos, para melhor atingir suas metas administrativas.

É eloqüente o fato de que a idéia tornou-se vitoriosa, com respeito ao serviço público, em primeiro lugar, no maior centro industrial do país que, por sua vez, exerceu influência fundamental na divulgação e posterior concretização da mesma no vizinho Canadá.

A vitória conseguida pela Prefeitura de Chicago motivou rápida expansão territorial do movimento na esfera da administração pública, fazendo com que oito Estados, quinze Cidades e muitos Condados se antecipassem ao Govêrno Federal, que só em 1923 viu realizado, apenas parcialmente, o anseio pioneiro há tanto tempo por muitos acalentado. Posteriormente, entretanto, medidas dêsse mesmo Govêrno, tal como a Lei de Segurança Social, vieram acelerar o ritmo dêsse movimento naqueles planos de administração, ao condicionar a concessão de ajudas federais ao aprimoramento dos métodos e processos burocráticos, do mesmo modo que durante a I Grande Guerra a elaboração de manuais de especificações de ofícios e a definição de títulos profissionais, para atender necessidades e conveniências nos meios militares, contribuíram de modo decisivo para o alcance das conquistas obtidas, nesse particular, no setor empresarial. 
Como vimos, de há muito já se concebia nos meios responsáveis do Executivo e do Legislativo o equacionamento dos problemas de classificação de cargos e fixação de salários em estágio bem mais adiantado do que se conseguiu alcançar com a Lei de 1883. Êsse descompasso aliado à comprovação na prática da insuficiência dos resultados obtidos com a execução daquele diploma legal fêz com que não arrefecesse a campanha em prol de medidas mais avançadas, a qual passou a contar também com a valiosa adesão da Comissão do Serviço Civil.

Com a constatação dos progressos atingidos na indústria $e$ nas outras áreas administrativas, tornaram-se insistentes no âmbito federal as tentativas reformistas, concernentemente à classificação de cargos e padronização de salários, num esfôrço de esclarecimento e convicção modelar e contagiante.

Assim, a partir de 1886 são freqüentes os pronunciamentos tanto da Comissão do Serviço Civil como de comissões executivas, legislatıvas e mıstas, no sentido de afirmar não só a conventência de que devem ser as tarefas inerentes aos cargos a base lógica da classificação, mas também a necessidade de um levantamento amplo, compreensivo e realístico constituir o fundamento correto da elaboração de um projeto de tal natureza.

Exemplos demonstrativos dêsse interêsse encontramos registrados em relatórios, projetos e discussões em 1886, 1902, 1905 , 1907 e 1908 como culminação de esforços denunciadores do aspecto de urgência caracterizante do empreendimento.

Tal como na Inglaterra e no Canadá, nos Estados Unidos e, de resto, em quase todo o mundo civilizado, foram marcantes as conturbações provocadas de 1914 a 1918 pela I Guerra Mundial, imprimindo caráter inadiável às reformas de muitos setores da coletividade em cada nação. No que tange à vida administrativa já vimos que êsse periodo assinala a inauguração de uma nova era, com a superação de hábitos, práticas, atitudes e usos gerais, testemunhando, ao mesmo tempo, inconformismos e inquietações na incessante busca de soluções imediatas para os problemas mais cruciantes e aflitivos oriundos do aumento em vultu e complexidade das organizações.

Por essa razão, e em face dos recursos técnicos disponíveis, cogitou o Govêrno Federal americano, logo após o fim das operações bélicas, isto é, em 1919, da criação de uma comissão mista interparlamentar encarregada de estudar e propor medidas relativas à classificação de cargos e padronização de salários, convicto que estava ser êste o remédio mais eficaz na cura dos males determinantes da conduta falha por parte da administração. Essa Comissão, em seu relatório ao Congresso em 1920, veiculou re- 
comendações coerentes com os princípios e técnica, cuja validade já havia sido experimentalmente comprovada em situações concretas no campo da administração estatal e de emprêsas.

Assim, a partir de 1923 passou também o Govêrno Federal norte-americano a contar com um plano de classificação de cargos racional, concebido segundo o modêlo pôsto à prova, com proveito compensador, não só pela indústria, como por outras :111idades administrativas, no âmbito nacional, e pelo domínio do Canadá.

Constituem feição principal comum a todos êstes planos: a existência de um órgão central controlador; a aceitação das tarefas executadas como fundamento da classificação; a elaboração de registros realísticos continuadamente atualizados; a análise e avaliação objetivas da natureza, dificuldade e responsabilidade inerentes às atribuições de cada cargo; unidade estrutural sistemática, com desdobramento em grupos homogêneos, segundo as afinidades ou semelhanças crescentes, tendo as classes como pontos terminais de reunião dos cargos; finalmente, tudo isto acompanhado de esclarecimentos minuciosos sôbre a utilização da classificação de cargos como instrumento de que não pode prescindir a ação de qualquer bom administrador.

A Lei de Classificação de Cargos de 1923, além de fixar as normas orientadoras de sua execução, para cujo fim foi criado - Conselho de Enquadramento de Pessoal (Personnel Classification Board), dispõs sôbre o esquema do plano, prevendo a existência de cinco Serviços com escalas de niveis respectivos, assim distribuídos: (1) Profissional e Científico com nove niveis; (2) Subprofissional com oito niveis; 3) Burocrático, Administrativo e Fiscal com 16 niveis; (4) Artifice, Conservação e Guarda com 10 niveis, e (5) Mecanização de Escritório com 4 niveis.

Cada um dêstes "Serviços" desdobrava-se em "Grupos Ocupacionais", êstes em "Séries de Classes", compostas de "classes" resultantes, por sua vez, da reunião de cargos similares. A cada classe correspondia determinado nivel da escala de graus aprovada para o Serviço respectivo. No mesmo nivel poderiam figurar classes diversas, desde que se assemelhassem em importância, responsabilidade e dificuldade do trabalho inerente aos cargos nela compreendidos.

As modificações posteriormente ocorridas com respeito ao Plano aprovado em 1923 foram de duas ordens: (a) aumento progressivo na área abrangida pelo Plano, decorrentemente da estratégia de início escolhida; $b$ ) consecutivos aprimoramentos de estrutura do esquema e funcionamento do sistema, em virtude dos progressos alcançados pela técnica de classificação de cargos dentro e fora do campo de atuação governamental. 
Assim, no presente, controlada pela Comissão do Serviço Civil, com a eliminação dos "Serviços" e instituição de uma só escala de "Niveis"; abrangendo todo o serviço público em vez de apenas parte dos cargos lotados na Capital do País, como originàriamente concebida; com a execução grandemente descentralizada, enquadra-se a classificação de cargos do serviço público federal norte-americano em padrões técnicos tão elevados quanto aquêles seguidos pelos setores mais exigentes de qualquer dos ramos da administração, pública ou privada, seja no nivel federal descentralizado, seja no estadual, no local, na indústria e no comércio ou nas organizações particulares de outra natureza. Por outro lado, as condições especiais, altamente favoráveis à frutificação da idéia, incrementadas na razão direta do progresso industrial, contribuiram, de modo decisivo, para elevar ao primeiro plano, no nivel internacional, o padrão técnico da classificação de cargos praticada na sociedade norte-americana, servindo de paradigma para os demais países, em têrmos de engenhosidade concepcional e eficácia de funcionamento.

Depreende-se do exposto que foi árdua a luta mantida pelas fôrças progressistas, tanto da Grã-Bretanha como do Canadá e dos Estados Unidos, no sentido de remover as múltiplas dificuldades surgidas durante a marcha em busca do aprimoramento das práticas administrativas. Em todos êsses países chegou-se à conclusão unânime, exuberantemente comprovada através dos fatos, de que para alcançar êsse objetivo é sempre de fundamıntal importância o papel exercido pela classificação de cargos, dadas as condições instrumentais que proporciona. Foi tal convicção, certamente, que os animou a dedicar tanta atenção e interêsse ao assunto, tratá-lo prolongadamente com prioridade, e lutar com vigor até levar a batalha a bom têrmo e plantar a semente de forma imorredoura.

Conhecido o panorama da classificação de cargos através do tempo naqueles países e sabida a influência de natureza econômico-politico-cultural que êles de há muito exercem sôbre a sociedacte brasileira, de forma efetiva e a ponto de condicionar nosso processo histórico, cumpre-nos agora estudar e analisar o comportamento nacional, desde a origem, em relação ao assunto.

\section{PLANO NACIONAL}

Classificação de Cargos no Brasil - Tal qual já vimos em relação à Grã-Bretanha, ao Canadá e aos Estados Unidos da América, também no Brasil é de capital importância recorrermos à fundamentação histórica para compreendermos a evolução do. fenômeno classificação de cargos através do tempo. 
Como já ficou esclarecido, durante longo periodo de desenvolvimento, a classificação de cargos, na sua fase embrionária, não se distinguia claramente dentro do processo administrativo global, nem podia, portanto, ser identificada ou considerada isoladamente como sujeito ou objeto em qualquer circunstância encarada. Tal contingência, universalmente válida, obriga-nos sempre, ao tentarmos traçar o perfil histórico da classificação de cargos, considerá-la indistintamente em conjunto com tôdas as práticas administrativas pertinentes às instituições compreendidas no campo de exame, isto, pelo menos, até ser possivel identificarlhe manifestações especificas denunciadoras inconfundiveis de sua individualidade.

Se encarada sob o prisma de sua conformação tecnológica, a história da evolução administrativa brasileira está ainda para ser escrita, fato êste que dificulta sobremaneira sua análise, apreciação crítica e formulação de conclusões pertinentes por parte de quem se proponha estudá-la ou discorrer a respeito de aspecto nela envolvido.

Entretanto, apesar da falta quase absoluta de dados e informes fidedignos, colhidos através de pesquisas objetivas especializadas que fundamentem conclusões concretas, não nos parece de todo inviável a formulação de algumas hipóteses corretas, elucidativas de tendências do desenvolvimento das práticas de classificação de cargos, estritamente sob sua feição técnica, tal qual ocorridas no meio brasileiro.

Assim é que o lastro teórico fornecido pela experiência estrangeira indica-nos a constante correlação existente entre desenvolvimento industrial e aprimoramento de práticas administrativas, marcando uma ordem cronológica, com o estabelecimento de etapas, no progresso da classificação de cargos, de modo geral em todos os países. Com efeito, em relação àquele constatamos sempre a existência de três fases, ou seja, uma pré-industrial, outra de concentração industrial e, finalmente, a última, de superconcentração industrial, sendo que na primeira se situa o estágio embrionário da classificação de cargos, na segunda a conscientizaçáo do problema e esforços de superação de dificuldades e na terceira a subconjugação de todos os obstáculos identificados na que the precedeu.

No Brasil, sendo válida essa ideação, podemos concluir que ainda estamos vivendo a segunda das mencionadas fases, isto é, atravessamos, nesse particular, período circunstancial correspondente àquele que antecedeu à I Grande Guerra, em relação aos países constituídos como paradigma de nosso desenvolvimento.

Com efeito, tanto na esfera empresarial como no âmbito do poder público não nos foi dado, ainda, sentir, em todo seu vigor, 
as necessidades que a concorrência capitalista e a complexidade em matéria de organização, inerentes à grande concentração industrial, acarretam com respeito ao aprimoramento de práticas administrativas e técnica gerencial. A falta dêsse estimulo necessário muito contribuiu, certamente, para nosso atraso na senda do progresso nesse campo da tecnologia.

No Brasil, é de notar-se os reclamos da industralização entre os quais, como já registramos, se alinha a necessidade de classificação sistemática dos cargos componentes das organizações de maior vulto - só há pouco se fizeram sentir, de modo veemente, demandando soluções viáveis para a nova problemática marcante da vida administrativa contemporânea.

Realmente, enquanto nos países citados e em muitos outros, a partir de meados do século passado, o capitalismo industrial fixava raizes e expandia-se, imperava aqui um acanhado capitalismu mercantilista, dentro de um quadro econômico onde predominavam valôres herdados, ainda, da sociedade feudal que nos deu origem. Nessa conjuntura que perdurou pràticamente até o término da II Guerra Mundial nem as emprêsas privadas, nem as instituições do poder público desenvolveram-se a ponto de, pelo vulto de sua complexidade, demandar alterações estruturais, metodológicas ou processuais, para ajustar-se a nôvo padrão de comportamento, ditado por necessidades de caráter imperioso \& inadiável.

Assim sendo, os ensaios de modernização administrativa esboçados ou concluídos até meados da década dos 40, empreendidos com o fito de emparelhar o Brasil, em têrmos de produtividade, com nações outras já em adiantado grau de desenvolvimento, apresentaram-se, lògicamente, impregnados de forfe dose de romantismo, bastante afastados da realidade, o que, fora de dúvida, prejudicou o equacionamento dos verdadeiros problemas, criando repercussões desfavoráveis sentidas ainda nos dias presentes.

Essa errônea enfocação do problema explica por que, não obstante as repetidas tentativas registradas desde o comêço do século, no sentido da realização de aperfeiçoamento no terreno da classificação de cargos, não conseguimos, até hoje, seja no dominio público, seja no setor privado de administração, alcançar progressos compativeis com o quadro de necessidades e anseios que, neste particular, compõe o panorama de nossa realidade nacional. Em sintese: quisemos obter mais do que deviamos e não chegamos a conseguir o de que precisávamos e estava dentro de nossas possibilidades levar a cabo.

Para provar essa assertiva, vamos a seguir procurar fazer uma análise do desenvolvimento da classificação de cargos nas 
diversas áreas do poder público e no setor privado de administração, ressalvando, desde já, os inconvenientes que a insuficiência de dados e a precariedade de informações acarretam a um trabalho dessa natureza.

Preliminarmente, porém, afigura-se oportuno fazermos alguns comentários sôbre certas qualidades típicas da mentalidade brasileira, oriundas de nossa formação histórica e condicionadoras da indole do comportamento coletivo nacional.

Devemos convir em que duas ordens de fatôres regulam sempre a ação dos indivíduos e dos grupos dentro das comunidades, sendo representadas por circunstâncias materiais e circunstâncias espirituais, traduzidas, ambas, respectivamente, por necessidades e anseios. Como ficou patente, no exame precedentemente levado a efeito, cada país apresenta, nesse particular, peculiaridades que explicam, por sua vez, a singularidade dos respectivos comportamentos no curso da história. Por outro lado, torna-se evidente que as necessidades resultantes de circunstâncias materiais são mutáveis e se adaptam à realidade específica de cada momento ou dela decorrem, ao passo que as tendências, traduzidas em anseios, têm caráter extṛatemporal e se afirmam como produto cristalizado através da vivência popular. Esse motivo dá pertinência à nossa intenção no sentido de antecipar ao exame cronológico de nossa evolução administrativa alguns comentários sôbre as fôrças espirituais condicionadoras dêsse desenvolvimento, principalmente tendo em vista que estas, ao contrário das outras, atuam de modo idêntico a qualquer época e em tôdas as áreas onde o fenômeno se manifeste.

Para bem compreendermos o comportamento do brasileiro e descobrirmos suas indoles e tendências é de fundamental importância retrocedermos às origens de sua formação no palco intra e extranacional.

Sob o aspecto antropológico, é bem sabido, descendemos, primordialmente, do indio americano, do branco europeu e do negro africano, dos quais herdamos uma mistura de dominantes elementos psico-etnológicos que atuam, de modo destacado, no cadinho de nossa civilização. Conforme o setor de vida encarado, podemos encontrar influências predominantes de uma outra origem, em virtude de condições de adequabilidade prática ou categorica sobrepujança de desenvolvimento do traço em considerações, de acôrdo com o meio ambiente e a atividade exercida.

No que tange aos problemas de natureza administrativa, com os quais ora nos preocupamos de modo exclusivo, é de notar $-s e$ - nítido domínio que a cultura européia exerceu sôbre as demais. Realmente, seja pelo grau superior de civilização do homem branco, seja pelo caráter político e prático imprimido à coloniza- 
ção e posteriormente aos nossos intercâmbios culturais, pode-se afirmar ter sido nula a contribuição que a cultura indigena e a africana ofereceram nesse campo de desenvolvimento da vida nacional. Aliás, poderse inclusive chegar à conclusão de que a inequivoca inferioridade dêstes últimos, com acentuado desnível de "status" social, prejudicou ou impediu todo processo de aculturação, favorecendo, ao contrário, a livre entrada da experiência carreada pelo português, intacta e imune a qualquer ajustamento positivo ao meio brasileiro. Por fôrça dessa circunstância, é de admitir -se mesmo tenha a atuação dêsses dois elementos, culturalmente despreparados, contribuido, ao correr do tempo, negativamente dentro do processo de aperfeiçoamento nesse campo da experiência nacional.

Posição singular à do índio e do africano coube, também, nesse particular, ao imigrante português que para cá se dirigiu em missão forçada ou, quando livre, privado de qualquer múnus público. A êstes, com raríssimas exceções, pelo menos durante os três séculos de colonização, não era dado interferir, de modo decisivo, nos assuntos de govêrno e, assim privados estavam de fazer sua ajuda cultural ao desenvolvimento do progresso dentro dêste setor de nossa civilização.

Finalmente, a descendência dessas raças que formavam o grosso da população do Brasil Colonial não tinha, por fôrça do regime de vida imperante, condições de exercer maior interferência em assuntos dessa ordem do que seus antepassados, em virtude dos processos, métodos e controles resultantes da política de colonização estabelecida pelo govêrno na metrópole.

Havia, portanto, nessa área, impossibilidade de fusão de culturas e, evidentemente, de revisão de valôres. Estes, gerados e consolidados em contexto social diverso, aliás alguns já completamente ultrapassados mesmo em seu meio, entravam, em vez de facilitar ou impelir, o deslocamento no sentido do progresso, principalmente dada a natureza do processo colonizador, desenvolvido mais com o objetivo de extrair e exportar riquezas do que plantar e sedimentar uma nova e promissora civilização.

Houve, așsim, condições genéricas, com efeitos prolongados, ocorridas no periodo colonial e capazes de exercer relevante função plástica na estruturação da alma brasileira. Dentre tais condições cumpre destacar: a) caráter do processo colonizador, mediante o qual tudo era imposto hieràrquicamente ao sabor da cúpula metropolitana; $b$ ) inferioridade racial e cultural do indio, do negro e do produto da miscigenação, fazendo prevalecer, de modo incontrastável, os valôres concernentes à cultura européia, e c) dando como consequiência, de modo geral, aceitação irrestrita, 
por parte da massa, do comando dos agentes colonizadores, seja por falta de discernimento para indicar melhor rumo, seja por incapacidade para fazer opções viáveis.

Tais circunstâncias explicam, certamente, a atitude acomodaticia dos brasileiros em relação à conduta do govêrno em qualquer nivel, o qual, forçosamente, assume feição paternalística, em face da ausência de pressões populares capazes de sintonizar a imperante conjuntura com a fenomenalidade da dinâmica social. Por outras palavras, pelo modo como foi tratado no periodo mais significativo para a formação de sua personalidade social, habituou-se o homem brasileiro a assumir uma atitude contemplativa em relação ao comportamento do poder público, ou, por extensão, do superior hierárquico, mesmo quando se torna agente dêsse poder, mantendo expectativa de que tudo se realize independentemente de sua intervenção. Por outro lado, a ação das esferas superiores, em virtude da falta dessa colaboração necessária, caracteriza-se, freqüentemente, por certa desvinculação da realidade, convertendo-se em falso modêlo ou paradigma orientador da conduta individual ou coletiva nas camadas inferiores da organização comunitária nacional.

Assim sendo, do mesmo modo que no Brasil Colônia os olhares gerais voltavam-se para a Coroa portuguêsa, no Brasil Império fixavam-se na Côrte e no Brasil República contemplam o Govêrno Federal, sempre através da escala hierárquica dos planos intermediários de autoridade, tidos como os verdadeiros responsáveis por tudo quanto devesse ou deva acontecer e tenha acontecido. Similarmente, por fôrça dos condicionamentos da política colonizadora, resultantes do caráter autocrático das determinações superiores, restounnos o vêzo de esperar que o progresso se origine sempre em cima e dai se propague verticalmente até atingir os grupamentos básicos, configurando-se atitude inversa àquela imperante no seio da sociedade norte-americana, como já foi oportunamente referido.

Observando-se os fatos por êsse prisma, compreende-se, fàcilmente, a razão não só de haver sido criado aqui inicialmente tipo de administração rigorosamente de acôrdo com o modêlo português, como ter êle prevalecido inalterado durante séculos, até quando padrão diferente, igualmente estranho ao meio e dessintonizado da realidade, veio tomar-lhe o lugar.

Após essas considerações preliminares, evocadas com o intuito de ensejar melhor entendimento dos fatos em exame, vamos tentar visualizá-los sob o ângulo cronológico de sua ocorrência no plano histórico e procurar extrair os ensinamentos que a experiência consolidada possa fornecer. 
Os tratadistas e comentadores dos aspectos politicos e sócioeconômicos de nossa história são concordes em admitir que Portugal, ao iniciar e dar prosseguimento à colonização do Brasil, procurou, sem qualquer originalidade ou esfôrço de adaptação, aplicar aqui instituições e normas administrativas iguais às que prevaleciam no território metropolitano, as quais, pelos motivos acima mencionados, como sejam, completa superioridade e dominio dos agentes colonizadores e primitivismo das condições mesológicas sócio-econômicas existentes, impedidoras ou retardativas da evolução normal do desenvolvimento, tenderam sempre a perpetuar-se inalteradas através dos séculos. Eis por que, segundo registram escritores preocupados com o assunto, em têrmos de práticas administrativas, o panorama dominante ao longo do periodo colonial manteve-se pràticamente inalterado durante o Império e ainda alcançou intacto grande parte da fase política republicana.

Diga-se de passagem que, nesse interregno, não havia aqui, fora do serviço oficial, condições minimas que ensejassem a manifestação de problemas ligados à classificação de cargos. Realmente, tanto na fase pré-capitalista, quanto, posteriormente, no capitalismo mercantilista e mais tarde nos primórdios do capitalismo industrial eram de caráter rudimentar e de reduzido porte os empreendimentos aqui implantados com o objetivo de explorar atividades artesanais, mercantis e inerentes à produção agricola ou extrativa, bem como à indústria de transformação, caracterizadoras de nossa economia nesses tempos. A pequena complexidade e a falta de consciência organizacionais tornavam extemporâneo qualquer esfôrço de racionalização tendente a redundar em mudanças de significado progressista, em têrmos de ação administrativa .

Só no âmbito do serviço público, dada a variedade, significação e amplitude do trabalho executado, era, pois, plausivel esperar-se preocupações dessa ordem, não fôssem os fatôres adversos existentes.

É que, em virtude de nossa formação histórica, faltava-nos. antes de tudo, a segurança e o equilibrio do senso realistico e a fôrça do sentimento ético, capazes de moldar a conduta do govêrno, tal como ocorreu nos paises anteriormente considerados. Lá e cá havia iniqüidade de tratamento e privilégios no seio do funcionalismo, imoralidade e ineficiência administrativa, desorganização e descontrôle do serviço público, cujos membros costumeiramente sobrepunham seus próprios interêsses aos interêsses comunitários.

Evidentemente, tal estado de coisas produzia descontentamentos generalizados em tôdas as latitudes, mas aqui o povo não estava preparado para lançar seu protesto através de represen- 
tantes autorizados ou categóricas manifestações populares e, assim, as vozes isoladas que tentavam fazer-se ouvir eram fàcilmente relegadas ao desprêzo ou sufocadas pela todo-poderosa burocracia, cuja mentalidade dominante estava impregnada de idéias e conceitos de cunho feudalista, de acôrdo com os quais sua conduta se afigurava normal e irreprovável. Dentro dêste quadro não havia lugar para padronização de comportamento, nem uniformização de tratamento no que tange aos empregados, linhas mestras em que se apóia tôda idéia de classificação de cargos.

Êsse complexo de circunstâncias, que pode ser resumido em fraco impacto da realidade, estagnação burocrática e ausência de reação popular, constitui o motivo principal do tradicionalismo deteriorante de nossa administração, cuja conduta reconhecidamente inadequada conservou-se durante quatro séculos sem sofrer significativo processo de revisão.

Só no inicio dêste século, por fôrça das implicações ligadas à Revolução Industrial, que começavam a ecoar entre nós, aliadas às novas formas dos métodos e processos políticos caracterizadores da vida republicana, que, num impulso de originalidade, repelia a tradicional cultura ibérica para apegar-se apressadamente ao modêlo anglo-americano, fizeram-se ouvir vozes esparsas, traduzindo inquietante inconformismo e advogando medidas modernizadoras no campo da administração pública de pessoal.

Bem ao estilo da época e de nossa mentalidade, é nitida a influência estrangeira sofrida por tais iniciativas, cujo fundamento irreal caracterizante de seu exotismo, ajudado pela fôrça da inércia burocrática e pela incompreensão e indiferença gerais, conduziu-as tôdas, sucessivamente, a completo malôgro, até que a vitória de alguns aspectos do pensamento burguês contidos na Revolução de 1930 veio modificar acentuadamente o panorama politico-administrativo do país e ensejar, no particular, as primeiras mudanças dignas de consideração.

Com o advento da República, o clima de ineficiência e imoralidade administrativa reinante por tão longo tempo nas repartições oficiais tornou-se mais carregado ainda, em virtude dos desmandos politicos e interferências indevidas das autoridades administrativas no processo eleitoral, resultante das novas práticas democráticas, situação essa fomentada pelo govêrno e tolerada, quando não aceita com prazer, pela opinião pública em geral.

A revolta contra tal estado de coisas de raro trazida à tona dos acontecimentos não era, comumente, fruto de agudo discernimento, nem de ardente idealismo, mas sim, de descontentamentos oriundos de interêsses feridos ou pretensões não completamente correspondidas no tabuleiro das competições politico-partidárias. 
Eis por que, em vez de se atentar para os problemas mais sérios da administração, de acôrdo com sua natural hierarquia prioritária, cogitava-se, em primeiro lugar, de reformas pouco significativas quanto a resultados práticos para a comunidade, mas de alto teor expressivo em têrmos de interêsses eleitoreiros. Focalizado o assunto através dêsse prisma, o mais importante não eram os aspectos organizacionais, disciplinares e éticos da vida administrativa do pais que até hoje, talvez por êsse êrro original de enfoque, continuam desconsiderados, mas sim as medidas aliciadoras de simpatias, pelas vantagens imediatas que concedem, sem nada exigir em contraprestação.

Essa incapacidade ou indisposição de primeiro diagnosticar - mal para depois indicar o remédio levou nossos precursores do movimento de modernização administrativa a tentar sempre corrigir os males crônicos de nosso serviço público federal mediante meras recomposições de situações funcionais, na ingênua esperança, é plausivel supor-se de que as falhas de comportamento ou funcionamento operacionais se eliminassem, por completo, automàticamente. Começávamos, portanto, onde os outros povos costumeiramente terminavam, isto é, estabelecíamos estimulos só justificáveis para atender o desígnio de melhorar o padrão dos serviços, já de si bastante aperfeiçoado pela preliminar supressão de vícios e defeitos incompativeis com a dignidade da função pública.

Por outro lado, a falta de senso realístico, defeito comum ainda no presente, colocava fora de nosso alcance as soluções técnicas de feição prática e conduzia-nos para um legalismo formal e improdutivo, de sentido meramente demagógico. De acôrdo com esta simplória e cômoda diretriz politica, assumiu plena validade entre nós o principio, segundo o qual a importação dos modelos estrangeiros mais adiantados podia verificar -se independentemente de qualquer assimilação ou adaptação ao meio circunstante.

Revelando, assim, uma preocupação mais com os problemas de relações formais entre o Estado e seus servidores do que com a organização, a eficiência e o funcionamento das repartições oficiais e a moralização administrativa, a partir da primeira década dêste século começaram a surgir, principalmente no Congresso Nacional, iniciativas de projetos perseguindo aquêle objetivo, os quais correspondendo, não a anseios gerais ou necessidades devidamente conscientizadas, mas sim a conveniências e desejos de âmbito limitado, não tiveram, por longo tempo, possibilidade de prosperar. 
Entre tais manifestações de cunho reformista são dignas de destaque, pela sua maior significação, as a seguir referidas.

O marco inicial dêsse séquito de reivindicações reformistas, que de certo modo tangenciava o problema da classificação de cargos, foi estabelecido pelo Projeto $n^{\circ} 320$, de 1907, apresentado à Câmara dos Deputados e de autoria de Justiniano de Serpa. Cogitava-se, então, de pôr têrmo ao caos existente com a adoção de providências avançadíssimas para o meio e para a época, impregnadas, portanto, de forte sabor romântico. Assim é que se cuidava de aspectos funcionais e organizacionais, dispondo-se sôbre direitos, deveres e condições gerais de ingresso e exercício dos funcionários, inclusive de sua classificação em quatro categorias, além de prever-se a estruturação de quadros e repartições. Como fàcilmente se depreende, principalmente se atentarmos para a predominância da influência inglêsa prolongadamente exercida sôbre a administração brasileira, de modo efetivo, desde as guerras napoleônicas, a semelhança entre a solução proposta e o que se praticava nos países atrás examinados não pode ser levada à conta de mera coincidência.

Foi inteiramente em vão êsse primeiro esfôrço, mas constituiu exemplo que dai em diante não parou de ser imitado.

Assim é que em 1910 procura Alcindo Guanabara renovar a tentativa e, em 1911, o Deputado Maurício Graccho Cardoso, através do projeto $\mathrm{n}^{\circ} 77$, visava a uniformizar a nomenclatura dos cargos públicos, acentuando que à mesma função devesse corresponder a mesma denominação, sem deixar de considerar, também, os aspectos atinentes às relações jurídicas entre o Estado e seus servidores. O Projeto $n^{\circ} 153$, de 1913, do Deputado Muniz Sodré seguiu as mesmas pegadas dos anteriores e teve idêntico desfêcho.

Não parou, no entanto, a insistência e logo em 1914 nôvo Projeto que tomou o número 212, de autoria do Deputado Camilo de Holanda, voltou a focalizar o assunto, prevendo inclusive normas tendentes à hierarquização dos cargos públicos, ałém das de caráter jurídico, já tradicionalmente consideradas.

Apesar dos insucessos, da indiferença da classe e da relutância dos politicos, continuou viva a idéia de modernização administrativa e, vez por outra, sob a forma de estatuto, de consolidação de legislação ou de reajustamento salarial, havia sempre quem persistentemente a trouxesse à tona e procurasse torná-la viável e efetiva. Assim foi no Govêrno Wenceslau Braz, assim foi no Govêrno Epitácio Pessoa. Neste período merece menção especial o Decreto $n^{?} 3.990$, de 2 de janeiro de 1920 , que autorizava o Presidente da República a rever os quadros do funcio- 
nalismo público civil, para o fim de classificar os lugares por categorias e, de acôrdo com estas, uniformizar-lhes os vencimentos respectivos. Não menos importante é o Relatório da Comissão prevista no mencionado decreto, publicado no Diário Oficial de 18-12-1921, o qual continha conclusões avançadissimas em matéria de classificação de cargos. Realmente, no primeiro documento, que concedia elevação de salários, era autorizado o Presidente da República a rever os quadros do funcionalismo público civil para o fim de classificar os lugares por categorias e de acôrdo com estas uniformizar-lhes os vencimentos, como se afirmava textualmente, podendo ainda, com êste objetivo, cuidar - Govêrno de alterar as denominações, número e atribuições dos empregados existentes. Em obediência a êsse comando legislativo, foi instituida comissão que, dois anos após, apresentou trabalho sério, submetido em seguida ao Congresso, onde se perdeu inaproveitado.

O relatório da Comissão, se bem que sucinto, deixa transparecer feições curiosas do trabalho levado a efeito, muito avançadas, sem dúvida, para a época, se considerado o meio. Assim é que, num trecho, ao afirmar textualmente "Na fixação de vencimentos atendeu a Comissão, tanto quanto possivel, à natureza e importância dos serviços, à categoria dos funcionários e à situação das repartições, tendo distinguido entre as repartições superiores e as que dependem dos Ministérios e entre estas e as que lhe estão subordinadas", ficou claro o propósito de o Govêrno guiar-se por uma ponderação equilibrada, fugindo à contingência de julgamentos subjetivos e pessoais. Noutro lugar afirma a Comissão categòricamente:

"Não se fêz reorganização de quadros, mas classificação de cargos e fixação de vencimentos. Dependendo das necessidades de cada repartição o número de seus funcionários, poderão as tabelas propostas ter aplicação qualquer que seja êsse número". Vê-se, pelo exposto, que havia uma compreensão clara do problema da classificação de cargos como instrumento de administração de pessoal, autônomo e independente dos demais, sendo, portanto, dado ao trabalho caráter bem distinto daquele inerente às clássicas reestruturações. Outro ponto digno de nota é o referente à questão da simplificação das nomenclaturas e da padronização dos salários, então satisfatòriamente equacionada.

Parlamentares, comissões executivas, mensagens presidenciais, de uma forma ou de outra, não deixaram mais cair o assunto no esquecimento, mas as fôrças conservadoras, encasteladas na cúpula decisória, mantinham-se surdas a tais apelos. O caos, a ineficiência e a imoralidade administrativas eram patentes, mas justamente dêsse estado de coisas vivia a politica partidária ex- 
traindo a seiva para seu dominio. Tanto a reorganização dos serviços, quanto o disciplinamento estatutário chocavam-se contra tais interêsses, como ficou bem salientado no seguinte trecho da Exposição de Motivos que encaminhou, em 1938, à deliberação do Presidente da República o Projeto de Estatuto dos Funcionários. Diz-se lá:

"A 15 de agôsto de 1929, de nôvo, o legislativo foi chamado a estudar a questão, por iniciativa do Deputado pela Bahia, Sr. Sá Filho, que demonstrou a inadiável necessidade de se cogitar do Estatuto, principalmente por que treze anos passavam da expedição do decreto $n^{\circ} 12.296$, que até então não lograra aprovação do Congresso. Nomeada uma comissão, da qual fizeram parte, além do proponente, os deputados Graccho Cardoso. Maurício de Medeiros, Henrique Dodsworth e Daniel de Carvalho, desincumbiu-se esta de sua missão, apresentando o projeto $n^{\circ} 425$, de 1929 , que, embora cuidadosa e pacientemente elaborado, com o intuito precipuo de atender às exigências superiores da Administração Pública e às justas e legítimas aspirações da classe, não obteve maior atenção do Legislativo, cujo desprêzo pelo assunto se explica fàcilmente pelo fato de não quererem os deputados privar-se de um dos seus principais "meios de existência política", abrindo mão da faculdade de livre escolha para o provimento dos cargos, com os quais premiavam a dedicação de sua clientela eleitoral. em detrimento do Serviço Civil. Esse o motivo por que, em 1911, o projeto Graccho Cardoso nem sequer foi objeto de parecer por parte da comissão encarregada de estudá-lo. Essa a razão, ainda, que determinou o fracasso de tôdas as tentativas posteriores, às quais opunha o Legislativo a fôrça da obstrução e da inércia, combatendo-as, surdamente, à socapa e às escondidas, como quem combate um inimigo perigoso e cruel. Eram, realmente, tais tentativas de moralização da administração pública, caso frutificassem, um golpe de morte no programa, então vigente, de se alimentar a mole imensa de cabos eleitorais e de chefes políticos à custa dos cofres públicos, com cargos polpudos e promoções imerecidas".

Efetivamente, a prática do sistema do mérito que constituia reivindicação constante em todos os projetos, a definição juridica do conceito de funcionário e a fixação legal da amplitude dos respectivos direitos e deveres, etapas preliminares para a con secução de objetivos mais altos e especializados, já bastavam 
para criar clima desfavorável aos desmandos, omissões e proveitos, tão caros a setores importantes da vida administrativa e politico-partidária do país.

Foi precisamente êsse estado de coisas, intolerável na conjuntura que a nação então vivia, o fator determinante da mobilização de expressivo setor da "intelligentzia" nacional, de origem civil e militar, que por todos os meios inclusive a violência buscava realizar as modificações sócio-políticas que o incipiente processo de desenvolvimento requeria com urgência.

Até a cúpula administrativa já estava convencida dessa necessidade, como dá conta a Mensagem Presidencial de 1929, que criticava os defeitos mais graves do sistema e traçava diretrizes para remediá-los, chegando mesmo a defender, veementemente, o princípio de igual salário para igual trabalho e afirmar com ênfase: "Para o desenvolvimento do Brasil, tão indispensável é a ordem pública, a estabilidade da moeda, o equilibrio do orçamento, o aparelhamento econômico, como a reorganização do funcionalismo".

Êste autorizado apêlo, entretanto, não foi ouvido a tempo e a conseqüência natural encontrou sua expressão própria no Movimento Popular vitorioso de 1930 , que pôs fim à Primeira $\mathrm{Re}$ pública.

Entre as idéias dominantes da Revolução de 1930 figurava o saneamento da vida politico-administrativa nacional e coerentemente com tal propósito não cessaram, desde os primeiros dias do Govêrno Provisório, as investidas nesse sentido. A primeira vitória concreta nesse particular só se efetivou, todavia, em 1934, com a inclusão na Constituição de um capítulo especifico dos funcionários públicos, onde já se fixavam as garantias especiais da classe e se previa a aprovação, através de legislação ordinária, do respectivo estatuto. Logo a seguir, por fôrça do que determinava a Lei $n^{\circ}$ 51, de 14-5-35, Executivo e Legislativo combinavam esforços para eliminar disparidades salariais, criando uma Comissão Mista para estudar convenientemente o assunto, em extensão e profundidade. Dêsse labor, não sem passar por sérios tropeços e obstáculos, originou-se a Lei $n^{\circ} 284$, de 28-10-36, que, indubitàvelmente, representa o marco mais expressivo dessa fase de nossa evolução administrativa.

Do estado caótico em que se encontrava a administração nos dá notícia o Relatório da chamada Subcomissão Nabuco, ao consignar:

"A Subcomissão sente-se obrigada a dizer que a desordem que encontrou nos quadros públicos excedeu às suas próprias expectativas. $\mathrm{O}$ atual aglomerado de 
cargos, que mal se pode chamar de quadro, com o qual se sobrecarrega o contribuinte, parece provir do acaso, da indiferença, do sentimentalismo, da incapacidade $e$ de injunções de tôda ordem".

Para remediar êsses males constatados, cuidou a Lei número 284 -36 de instituir o Conselho Federal do Serviço Público Civil e, em cada Ministério, uma Comissão de Eficiência, além de estruturar os quadros de pessoal, dispor sôbre a nova sistemática de distribuição dos cargos e prever a profissionalização e o sistema do mérito, que iriam reger a vida do funcionalismo.

Como manifestamente declarado em documentos oficiais, a Lei $n^{\circ}$ 284-36 fundamentou-se no aproveitamento das lições inglêsa e norte-americana, o que não é difícil de compreender-se, caso atentemos não só para as providências cogitadas em seu bojo, como, também, para as influências político-culturais que aquêles paises exerciam sôbre o nosso.

Houve preocupação salutar com a existência do órgão central de pessoal, com o sistema do mérito e com o ordenamento dos cargos para ensejar uniformidade de tratamento, pontos básicos de partida para efetivação de um bom programa de administração em qualquer entidade de certo modo complexa. Não se pode ignorar, entretanto, principalmente tendo em vista como relatado com respeito ao Canadá e aos Estados Unidos, que a solução arquitetada alicerçou-se em experiência alienigena correspondente a estágio de evolução e a realidade bastante dissemelhantes daquilo que era aqui presenciado.

No que tange ao reconhecimento da necessidade de contrôle central para assegurar unidade de programa e uniformidade de ação através de tôda a estrutura administrativa, levou em conta a Lei $n^{\circ} 284-36$ o avanço conseguido, a duras penas, pelo Canadá e pelos Estados Unidos, mas com respeito à classificação de cargos desprezou o exemplo dêsses dois paises, para apegar -se, em suas linhas gerais, ao modêlo original britânico, que nem onde predominava a semelhança de cultura e tradições dera certo.

A falta de definições onde inexistia estabilidade de conceituação profissional; a ausência de registros de cargos quando ninguém sabia o que lhe competia fazer, e a carência de atualização continuada em face de uma realidade só precàriamente conhecida e permanentemente cambiante, não podia conduzir o projeto a bom têrmo, como já sobejamente comprovara os exemplos canadense e norte-americano. Faltou, evidentemente, por parte de nossa administração, uma vivência real da evolução do problema, mediante a qual se criasse um lastro de experiência e uma cons- 
cientização própria, capazes de facilitar-lhe o equacionamento, sem perder de vista as peculiaridades inerentes ao meio, e incutir o ânimo necessário à efetivação da respectiva solução.

A reforma de 1936, fiel à tradição, manteve a validade da idéia de "status" do funcionário, em vez de valorizar o conceito de cargo, para o fim de enfrentar contingências de ordem sócioético-culturais, como já fizeram o Canadá e os Estados Unidos. Talvez nesse fato se resuma a principal causa do relativo insucesso daquele diploma legal, em têrmos dos objetivos de eficiência e moralidade administrativa perseguidos por seus idealizadores.

Essa falha de concepção deve, também, ser debitada aos agentes executores da reforma, que perderam, nos anos que se seguiram, excelentes oportunidades de fazer muito de positivo, em benefício do aprimoramento da classificação de cargos na área da administração federal, adaptando às suas necessidades a lição da experiência estrangeira posta ao nosso alcance, vivida em circunstâncias bastante similares. Com efeito, o advento do chamado Estado Nôvo, da Constituição de 1937 e do DASP nela previsto, aliado à nossa indole conformista e à expectativa de profundas modificações de iniciativa e natureza governamental, criou condições adequadas ao lançamento de medidas até então tidas como inviáveis ou só realizáveis após a transposição de penosos obstáculos. Isso tem maior pertinência, dinda, se levarmos em conta que a partir de 1938 começamos a ter maior facilidade de estabelecer contatos mais intimos com a experiência anglo-americana, relacionada com a melhoria do padrão de funcionamento do serviço público, enviando, inclusive, sucessivas turmas de estagiários que se familiarizaram, nos minimos detalhes, com os progressos atingidos por aquêles povos, ficando, outrossim, em condições de assimilar e pôr aqui em prática o precioso "Know-how" por êles concebido e utilizado.

Não obstante o exposto, nota-se, na linha de ação do govêrno, durante todo o Estado Nôvo, completo desinterêsse pelo aspecto técnico da classificação de cargos, como se, nesse partitular, nada de melhor fôsse mais possivel realizar. Conservavase, com zêlo especial, a sistemática introduzida pela Lei $n^{\circ} 284 / 36$, complementando-a com disciplinamentos e definições de efeitos meramente formalisticos, sem atentar para os resultados em têrmos de rendimento prático. Assim é que se aprovavam, abundantemente, códigos, leis, regulamentos etc. pertinentes à administração de pessoal, mas tudo funcionava deficientemente, por falta do suporte próprio em que apoiar - se.

Não havendo, portanto, apesar das boas intenções, clima propicio ao estabelecimento de padrões de conduta e uniformidade de tratamento em ampla escala, os esforços nesse sentido. 
desde o recrutamento até o afastamento dos empregados públicos, jamais conduziam a resultados satisfatórios, verificando-se, a despeito da aparente ausência de desmandos que um certo comportamento austero fazia presumir, não poucas iniqüidades e generalizada desorganização e ineficiência nas rẹpartições federais

Em ambiente dessa ordem era fraco o sentimento de adesão e intensas as ondas de descontentamento. A conseqüência natural de tudo isso foi que, em 1945, com a cessação do Estado Nôvo, ruiu fragorosamente o edifício, em virtude da incontida violência da reação.

A incompreensão, aliada ao saudosismo, empreendeu a tarefa de pôr fim a êsse movimento de indole renovadora e não poupar esforços no sentido de apagar-lhe todos os vestígios. Para tanto mutilou leis e instituições marcantes, surgidas nesse periodo, e desandou a fazer concessões, as mais destemperadas possiveis. Não contou, porém, que combatia uma idéia-fôrça, a esta altura já profundamente enraizada em expressivas camadas populares, de cujos interêsses participava, e apoiada em experiência teórica e prática por ela própria criada, de utilidade indubitável.

No que tange à classificação de cargos, as deficiências do sistema introduzido pela Lei $n^{\circ} 284 / 36$, a conscientização do problema conseguida através de sua vivência prática e teórica, bem como a balbúrdia gerada pela atuação revanchista daquelas mentalidades viciadas ou pouco esclarecidas, determinavam, a partir de 1951, quando ventos benéficos começaram a soprar, reação salutar que fazia prever dias melhores para a arrumação técnica de nossa administração.

Assim foi que o eco de vozes isoladas começou a fazer-se ouvir na esfera do Poder Executivo e no Parlamento, tornando-se cada vez mais forte e autorizado. Manifestações expressivas dêsse movimento renovador figuram nas Mensagens Presidenciais ao Congresso Nacional referentes aos anos de 1951 e 1952, bem como nos debates travados na Câmara dos Deputados em tôrno do nôvo Estatuto dos Funcionários.

Reconhecida a superação do sistema aprovado pela Lei número 284/36; o caos reinante nas repartições públicas; a necessidade de reaparelhar a administração para cumprir a missão que lhe era designada, e a conveniência e propriedade de adotar-se uma classificação de cargos fundamentada nas atribuições e responsabilidades cometidas aos empregados, a conseqüência lógica foi a inclusão do art. 259, da Lei $n^{9} 1.711$, de 28-10-52, determi nando a elaboração pelo Poder Executivo de um racional plano de classificação, a ser submetido ao Congresso no prazo de dois anos. 
Era, finalmente, chegada a oportunidade, há tanto tempo esperada, em que a cúpula do Govêrno buscava unida solucionar, de modo efetivo o magno problema da classificação de cargos, traçando a politica e esquematizando o objetivo, de modo adequado e definido. Cumpria ao nível executivo, isto é, àqueles encarregados da fase operacional do projeto, transformar a idéia e o propósito em realidade, e esforços não foram poupados nesse sentido.

Designou-se, de imediato, uma comissão provisória e logo a seguir outra definitiva que, enfrentando tôda espécie de dificuldades, conseguiu dar pronto o trabalho dentro do prazo prescrito. Enviado êste, sem demora, ao Congresso Nacional, sofreu longa tramitação, transformando-se, seis anos depois, na Lei n' 3.780, de 12-7-60.

Só nas fases práticas de elaboração e aprovação do projeto percebeu-se o defeito ótico de enfoque da questão. De fato, a administração, os politicos e a opinião pública em geral não estavam devidamente preparados para vencer a extensão do salto. Faltava-lhes, necessàriamente, não só a compreensão no grau requerido, como suficiente "Know-how", capaz de possibilitar o conveniente equacionamento e conseqüente solução própria do problema. Por outro lado, nosso senso de comodismo, conjugado com o retrocesso involutivo registrado nos anos anteriores, féz com que não se cogitasse, no momento oportuno, de medidas tendentes. a criar clima mais favorável ao desenvolvimento dos trabalhos. de implantação e administração do plano.

Como resultado disso tudo, obtivemos, apenas, um arremêdo de classificação de cargos, pois o plano em aprêço, além de ter sido mal elaborado, foi pior discutido e pèssimamente emendado e executado, dando lugar a problemas gravíssimos, sem conseguir resolver aquêles justificadores de sua existência.

Faltou-nos, evidentemente, competência para criar condições desejáveis, orientar o curso dos acontecimentos e conceber soluções adequadas em face das circunstâncias atuantes, restando-nos, agora, esperar, apenas, que, o futuro, o proveito dessa experiência favoreça a superação de tais dificuldades e impeça o advento de defeitos de natureza semelhante impeditivos da consecução dêsse objetivo.

Segundo os traços psicológicos caracterizadores da mentalidade do brasileiro na sua getieralidade, era de esperar-se que a administração federal exercesse função pioneira e desbravadora na concretização dessa idéia e, assim, realmente aconteceu. Apesar dos obstáculos e reveses assinalados, o trato do problema não conseguiu, em qualquer outro setor da vida nacional, assumir 
categórica posição de vanguarda ou apresentar, de modo insofismável, maior indice real de progreșso.

Como já foi observado, atendendo-se ao aspecto do amadırecimento desenvolvimentista, isto é, da convergência de condições determinantes de necessidades e geradoras do problema, em face das quais se tornasse imperativa a existência do plano de classificação de cargos, nenhuma outra instituição, pública ou privada, neste país, podia competir com a União Federal, pois representava ela, indiscutivelmente, a maior e mais complexa emprêsa em funcionamento. No seu âmbito, entretanto, só na esfera do Poder Executivo constata-se a prevalência dessas circunstâncias, sendo esta uma das razões por que a evolução da idéia continua pràticamente na estaca zero, dentro dos Podêres Législativos e Judiciários.

$\mathrm{Na}$ área estadual são poucas as tentativas dignas de menção. Além do esfôrço pioneiro sustentado pelo Rio Grande, do Sul no fim da década dos 40, São Paulo, Minas Gerais e Guanabara, seguindo as pegadas do Govêrno Federal, de cuja ajuda técnica de um modo ou de outro se beneficiaram, a partir dos meados da década dos 50 empenharam-se em tarefa semelhante, mas todos êles, seja por imaturidade de desenyolvimento, seja por falta de meios, não conseguiram resultados compensadores, em têrmos de objetivos focalizados. Nessas experiências, tal qual deu exemplo o Govêrno Federal, tem sido comum a nota de irrealismo na fase de elaboração dos projetos; balbúrdia, por efeito de interferências ilegítimas, nas aprovações, e improvisação, para adaptá-los à situação concreta e conseguir salvar algo, quando da execução. Respondem, em primeiro lugar, por essas conseqüências, a desorganização dos serviços onde, não havendo registros dos cargos completos e atualizados, torna-se impossivel fazer-lhes as convenientes identificações; alheamento ao problema e conseqüente falta de participação no que respeita aos possiveis interessados, e, finalmente, a pouca presșão ocasionada por necessidades que atuam mais vigorosamente em outras direções. A tudo isso soma-se a falta de sentido que uma medida dessa ordem sempre apresenta, se adotada onde inexiste programa racional e efetivo de administração de pessoal, e que possa servir de fundamento.

$\mathrm{Na}$ área municipal o atraso é bem maior, pois poucas comunas contam com o sistema de pessoal plausivelmente organizados, e, assim, muitos passos ainda faltam ser dados para ter cabimento o interêsse pelo problema. Mesmo entre os municipios das capitais, segundo as informações ao nosso alcance, só São Paulo, Belo Horizonte, Pôrto Alegre, Brasília, Recife e Salvador demonstraram preocupações pelo assunto, mas, pelas razões e cir- 
cunstânciass acima examinadas, não conseguiram indice expressivo de progresso, ficando aquém do ponto atingido pelos modelos nacionais em que se basearam.

No setor privado, foi em virtude das circunstâncias criadas pela II Grande Guerra que começou a se formar ambiente propício à implantação de métodos modernos de administração e, conseqüentemente, a ser valorizada a técnica de classificação de cargos e ter cabimento seu emprêgo e conjugação de esforços tendentes a aperfeiçoá-la.

Pode-se, efetivamente, tomar como início da fase de concentração industrial do capitalismo brasileiro a criação da Companhia Siderúrgica Nacional. Desde, então, os anseios e necessidades causadores e conseqüentes do processo desenvolvimentista não cessaram de atuar no sentido de fazer surgir novos grupamentos organizacionais de vulto e crescente complexidade. A exploração dos potenciais energéticos, a desconcentração de atividades estatais e o intervencionismo no dominio econômico, a indústria automobilistica, os grandes empreendimentos industriais, comerciais e financeiros, as múltiplas especializações profissionais deram lugar a importantes aglomerados de cargos que, pelo respectivo número e natureza, estavam a exigir tratamento especifico, racional e metôdico em relação a cada uma das variadas categorias representadas.

Para conseguir essa atualização de atitudes e comportamento, o. caminho certo que a experiência vivida alhures indicava cra o emprêgo da classificação de cargos, e passos nesse rumo foram dados.

A pouca divulgação em tôrno do assunto, comum, aliás, nesse estägio de desenvolvimento, não nos possibilita dispor de informa. çổes completas e atualizadas sôbre os progressos já atingidos no campo em aprêço. Certas coordenadas lógicas, entretanto, favorecem a formulação de hipóteses, cuja confirmação se nos afigura bastante viável.

A inconsistência da motivação que o atual estágio de desenvolvimento industrial tende a acarretar; a relativa pequena experiência que o trato do problema nos proporcionou; a pobreza do mercado de trabalho no que tange à disponibilidade de profissionais especializados; a dificuldade de formação de especialistas; a ausência de conjugação de esforços necessários à realização de aperfeiçoamentos consideráveis são indícios bastante expressivos. que nos levam a concluir ser impossivel encontrarmos grandes conquistas nesse campo de atividade. A tudo isto junta-se a circunstância ponderável de serem as organizações de maior vulto e complexidade, onde, portanto, são mais impositivas as necessi- 
dades de aperfeiçoamento e especialização e maior a capacidade de resolver os problemas decorrentes, quase tôdas de natureza semipública e tendentes a se inspirarem no modêlo federal, cuja ajuda técnica procuram obter mediante a requisição de pessoal especializado.

De todo o exposto, pode-se concluir que, tanto na administração pública, como no campo empresarial, nossas tentativas de equacionar o problenıa da classificaçáo de cargos não conseguiram atingir o êxito desejado, isto é, o progresso alcançado não corresponde aos reclamos oriundos do desenvolvimento econômico brasileiro, no seu estágio atual. Deve-se isto ao nosso despreparo técnico e psicológico e à nossa formação cultural inadequada, agravado pelo reiterado êrro de encaminhamento de soluçõę pouco práticas e apressadas.

$\mathrm{Na}$ realidade, apesar da aparência imponente que alguns planos em funcionamento possam mostrar como resultado de certa sofisticação formal dispensada no trato do assunto, encontramonos, ainda, na melhor das hipóteses, titubeantes na identificação dos verdadeiros obstáculos a enfrentar e na definição das metas próprias a atingir, impossibilitados, portanto, de idealizar o instrumento convenientemente adequado às contingências do meio brasileiro.

Finalmente, resta-nos esperar que a experiência acumulada, somada às motivações acarretadas pelas implicações inerentes ao processo desenvolvimentista, proporcione, daqui para frente, aperfeiçoamentos progressivos, em todos os setores, da técnica e do processo da classificação de cargos, aparelhando-nos para fazer face às necessidades emergentes a cada momento e trocando por outra mais alegre a atual paisagem administrativa comentada.

Raymundo Xavier de Menezes - Diretor da Divisão de Classificação de Cargos do DASP. 